\title{
SIMÓN RODRÍGUEZ LASO, UN CLÉRIGO ILUSTRADO EN EL COLEGIO DE SAN CLEMENTE DE LOS ESPAÑOLES
}

\author{
POR \\ Carlos Nieto SÁnchez \\ Doctor en Historia Contemporánea. Profesor de IES Madrid
}

\section{RESUMEN}

Simón Rodríguez Laso (Montejo, Salamanca, 1751, Bolonia, 1821) Doctor en Cánones por la Universidad de Bolonia, dignidad de de maestrescuela de la S. I. catedral de Ciudad Rodrigo, caballero de la Orden de Carlos III y rector del Colegio de San Clemente de Bolonia desde 1788 hasta su muerte en 1821. En este artículo se pretende dar a conocer la etapa italiana de un ilustrado español, que luchó por la supervivencia de una institución característica del Antiguo Régimen, el Colegio de San Clemente de los españoles de Bolonia, que resistió a la ofensiva del liberalismo. En el artículo se quieren también destacar algunos rasgos de la personalidad de Laso, ilustrado y regalista, que vio mitigado su pensamiento reformista por las nuevas ideas que surgieron de la Revolución Francesa y que consagró su vida al Colegio hispánico de Bolonia.

Palabras Claves: Simón Rodríguez Laso, Ilustración, Colegio de San Clemente de los Españoles, dominio francés en Italia, liberalismo.

\section{SIMÓN RODRÍGUEZ LASO, A CLERGYMAN ILLUSTRATED IN THE SPANISH COLLEGE OF SAN CLEMENTE}

\begin{abstract}
Simón Rodríguez Laso (Montejo, Salamanca, 1751, Bologna, 1821) Doctor of Law for the University of Bologna, Dignity of the Maestrecuela of the Cathedral of Ciudad Rodrigo, Knight of the Order of Carlos III and Rector of the College of San Clemente (Bolonga, Italy) from 1788 until his death, in 1821. This article seeks to highlight the Italian stage of a Spanish Enlightenment men, who fought for the survival of a characteristic institution of the Ancien Regime, San Clemente of the Spaniards College, which resisted the offensive of
\end{abstract}


liberalism. The article also underlines Laso's personality, learned and regalist, he saw off his reformist thinking because of the new ideas that emerged from French Revolution and devoted his life to the Hispanic College of Bologna.

KEY WORDS: Simón Rodríguez Laso, Enlightenment, College of San Clemente, French rule in Italy, liberalism.

Recibido/Received 19-07-2010

Aceptado/Accepted 18-01-2012

Laso, el instante que llamamos vida, ¿es poco breve, di, que el hombre deba su fin apresurar? O los que al mundo naturaleza dio males crueles, ¿tan pocos fueron, que el error disculpen con que aspiramos a crecer la suma?

Leandro Fernández de Moratín

La Ilustración española cuenta con algunos personajes poco conocidos. Uno de ellos es Simón Rodríguez Laso, rector del Colegio de San Clemente de los españoles de Bolonia. Simón Laso fue un sacerdote que, tras estudiar en Salamanca, entró en contacto con las ideas ilustradas italianas, al obtener una plaza en el Colegio español de Bolonia del que años más tarde sería rector. En la Italia que Laso conoció fue donde se difundieron con fuerza las teorías jansenistas que tuvieron influencia en su pensamiento, al igual que en el de su hermano Nicolás, relacionado con el grupo filo-jansenista español establecido en Valencia. ${ }^{1}$

No puede decirse que el personaje sea desconocido para los investigadores. Desde hace varias décadas, el profesor Antonio Astorgano ha dado a conocer algunas pinceladas de su vida. Lo ha hecho a través de importantes artículos, pero fundamentalmente gracias al estudio crítico del Diario en el viage de Francia e Italia de Nicolás Rodríguez Laso, donde publica una biografía de Simón. Pese a todo, y como el mismo profesor Astorgano afirma, el estudio biográfico de Simón Laso se remite, fundamentalmente, a sus años españoles, aportando sólo algunos detalles de su estancia en Bolonia, concretamente aquellos que ponen de manifiesto la unión entre los hermanos. ${ }^{2}$ Queda por conocer, por tanto, la etapa italiana de Simón Laso.

\footnotetext{
${ }^{1}$ Astorgano Abajo, A. 1998. «La personalidad del ilustrado Don Nicolás Rodríguez Laso (17471820), inquisidor de Barcelona y Valencia». Revista de la Inquisición 8: 121.

${ }^{2}$ Rodríguez Laso, N. 2006. Diario en el viage de Francia e Italia (1788): 96. Zaragoza: Institución Fernando el Católico.
}

Hispania Sacra, LXV

131, enero-junio 2013, 275-308, ISSN: 0018-215-X, doi: 10.3989/hs.2013.009 
En este artículo se pretende completar la biografía de Laso estudiando con cierto detenimiento su larga estancia en Bolonia, de más de treinta y tres años, hasta ahora desconocida. Fueron aquellos unos años turbulentos para la fundación aegidiana: los años en los que el Colegio, con Laso a la cabeza, tuvo que luchar por su propia supervivencia amenazada por los envites de los gobiernos franceses. El enfrentamiento con la República Cisalpina o la clausura del Colegio por Napoleón son sólo algunos de los muchos obstáculos que superó en Bolonia, con éxito y tesón, este clérigo ilustrado.

\section{ESPAÑA-BOLONIA-ESPAÑA}

Simón Rodríguez Laso nació en Montejo, Salamanca, el 13 de marzo de $1751 .{ }^{3}$ Era el segundo de los ocho hermanos habidos en el matrimonio de sus padres, Fernando Rodríguez y María Antonia Martín Laso, labradores y ganaderos de una posición relativamente desahogada, tal y como se colige del Catastro del marqués de la Ensenada. ${ }^{4}$ Aunque no consta que ninguno de sus progenitores litigara su hidalguía en la Chancillería de Valladolid, ${ }^{5}$ debían ser tenidos por hidalgos en aquella villa, según el expediente de concesión de la Real y Distinguida Orden de Carlos III que le fue otorgada por el Rey poco tiempo después de su llegada a Bolonia.

Realizó estudios de cánones y leyes en la Universidad de Salamanca, donde había sido manteísta, y en esta ciudad fue ordenado sacerdote. ${ }^{6}$ Como bachiller en ambas materias aparece en las letras presentaticias que Manuel de Roda, ministro de Gracia y Justicia, envió al Colegio de San Clemente de los españoles de Bolonia para que ocupara una de las plazas y en donde obtuvo el título de Doctor en Cánones. Fue admitido por el rector Joaquín Quintano en 1773, permaneciendo en Bolonia tres años, en los cuales fue consiliario, secretario y

\footnotetext{
${ }^{3}$ Su genealogía paterna y materna fue publicada en 1987 por Vicente de Cadenas y Vicent en Extracto de los expedientes de la Orden de Carlos $3^{\circ}, 1771-1847$, tomo XI: 61-62. Madrid: Hidalguía.

${ }^{4}$ Según el Catastro del marqués de la Ensenada, las propiedades de los Laso en el lugar de Montejo en 1752, se limitaban a una tierra que producía dos fanegas y media de trigo y media de centeno, una parte de tres de una casa en el casco de la localidad, de una habitación baja y corral, y una tercera parte de un pajar. Su ganadería se componía, en aquel momento, de 174 carneros. Para la labor agrícola y ganadera que se realizaba en su casa había dos criados. Archivo Histórico Provincial de Salamanca, Catastro del marqués de la Ensenada del lugar de Montejo, ref. 1532, pp. 47-50.

${ }^{5}$ No aparecen ni sus padres, ni sus abuelos ni bisabuelos en la relación de litigantes en los diferentes pleitos de hidalguía en la Chancillería de Valladolid, publicados por Alfredo Basanta de la Riva en su obra Sala de los Hijosdalgo. Catálogo de todos sus pleitos, expedientes y probanzas. Madrid: Hidalguía. 1955.

${ }^{6}$ Rodríguez Laso, N. 2006: 82.
} 
celario. ${ }^{7}$ Durante su estancia en el Colegio, según el testimonio de uno de sus compañeros, Ignacio Martínez de Villela, fue un joven de «excelente conducta, ilustración y aplicación a todo género de literatura». ${ }^{8}$

En 1774 marchó a Roma en compañía del rector Quintano. Allí entró en contacto con el arzobispo de Sevilla, Francisco Solís Folch de Carmona, del que obtuvo una recomendación papal para ocupar el cargo de maestrescuela de la catedral de Ciudad Rodrigo, reservado en el concordato de 1753 a la Silla Apostólica. ${ }^{9} \mathrm{Al}$ tomar posesión de la prebenda eclesiástica, en 1776, su plaza de colegial se declaró vacante. Durante su estancia en la fundación albornociana fue compañero de algunos de los hombres notables de la administración y la Iglesia en el reinado de Fernando VII: Ambrosio López de Momediano, canónigo de Segovia; Luis de Urriola, más tarde rector del Colegio y oidor regio en la Audiencia de Santiago de Chile; Carlos de Simón Portero, alcalde del crimen en la Chancillería de Granada y regente de la Audiencia de Oviedo; Ignacio Martínez de Villela, auditor criminal en la Chancillería de Granada y alcalde Casa y Corte; Domingo Fernández Campomanes, alcalde de Corte del Consejo de Navarra; Francisco Javier Almonacid, obispo de Palencia o Antonio José Salinas y Moñino, sobrino del conde de Floridablanca. ${ }^{10}$

Siendo maestrescuela de Ciudad Rodrigo, desempeñó importantes cargos en el gobierno de la Diócesis. En 1781, tras la muerte del obispo Alvarado, fue nombrado notario mayor. ${ }^{11}$ En el cabildo extraordinario, convocado tras de la muerte del obispo Ildefonso Molina, en diciembre de 1784, se vota por arquillas los oficios en sede vacante y «salieron por maior número de votos, nombrados Provisores y Governadores de este obispado, los Sers. don Manuel de la Peña y Zepeda, Arcediano de Sabogal y Canónigo Doctoral, y don Simón Rodríguez Laso, Maestrescuela», que además fueron designados gobernadores del seminario. ${ }^{12}$

En 1785, aunque no aparezca expresado como tal en el Libro de Acuerdos Capitulares, ejercía funciones de vicario general de la Diócesis. Así lo atestigua

\footnotetext{
${ }^{7}$ Pérez Martín, A. 1979. Proles aegidiana, tomo III: 1694-1698. Zaragoza: Cometa.

${ }^{8}$ Archivo del Ministerio de Asuntos Exteriores de Madrid, Ignacio Martínez de Villela a Pedro de Cevallos, Madrid, 25 de mayo de 1815, leg. P-822. exp. 11601.

${ }^{9}$ Archivo del Santuario de Loyola, Diario del padre Luengo, tomo IX, fol. 200. La bula de nombramiento se conserva en el archivo catedralicio de Ciudad Rodrigo y está fechada en Roma el 5 de mayo de 1775. Archivo de la catedral de Ciudad Rodrigo, Libro de Acuerdos Capitulares, $\mathrm{n}^{\circ} 19$.

${ }^{10}$ La biografía de todos ellos aparece publicada por Antonio Pérez Martín en la Proles Aegidiana, haciendo especial hincapié en sus estudios y estancia en Bolonia. En Pérez Martín, A. 1978. tomo III: 1681-1707.

${ }^{11}$ ACCR, Libro de Acuerdos Capitulares, ${ }^{\circ} 20$.

${ }^{12}$ Ibid.
} 
un poder fechado en septiembre de 1785 que comienza diciendo: «Nos, el Lzdo don Manuel de la Peña y Zepeda, Arcediano de Sabogal y Canónigo Doctoral, y el Dr. don Simón Rodríguez Laso, Dignidad de Maestrescuela de la Sta Iglesia Catedral de Ciudad Rodrigo, Provisores Governadores y Vicarios generales de ella y su obispado». ${ }^{13}$

En 1779 fue nombrado comisario del Santo Oficio en la ciudad de Valladolid, tras haber presentado de forma conjunta con su hermano Nicolás la instancia para obtener dicho cargo. Nicolás fue nombrado comisario de la Inquisición en Madrid y seguiría su carrera en aquel tribunal. Contrariamente, Simón nunca haría mención en Bolonia de su relación con esta institución. ${ }^{14}$

Simón Laso compaginó su dignidad eclesiástica con la de secretario de la Sociedad Económica de Amigos del País de Ciudad Rodrigo, aprobada por Real Cédula en 1781, siendo uno de sus promotores. La primera junta pública de la misma se celebró el 5 de enero de 1782. Estaba entonces formada por 197 socios donde casi la mitad eran presbíteros. ${ }^{15}$ Laso ejercerá en la junta de gobierno de primer secretario y fue el encargado de pronunciar la oración fundacional. En los años posteriores fue nombrado académico correspondiente de la Real Academia de la Historia ${ }^{16}$ y honorario de la de Bellas Artes de San Fernando. ${ }^{17}$

Todas las obras que se conocen del presbítero Laso fueron escritas antes de su marcha a Bolonia. Aguilar Piñal cita concretamente cuatro: Oración fundacional de la Sociedad Económica de Ciudad Rodrigo y Oración gratulatoria que el Sr. D. Simón Rodríguez Laso hizo a la Academia de la Historia por su admisión en la clase de correspondiente, ambas como manuscritos, y la Oración sobre la excelencia del dibujo, (Madrid, imprenta de Antonio de Sancha, 1782) y el Elogio del Sr. D. Antonio del Águila, Marqués de Espeja pronunciado por el Dr. D. Simón Rodríguez Laso, dignidad de Maestrescuela de la Santa Iglesia Catedral de Ciudad Rodrigo, Secretario de la Real Sociedad Económica de dicha Ciudad, e individuo de la Real Academia de la Historia en

${ }^{13}$ Ibid.

${ }^{14}$ Archivo Histórico Nacional, Informe del Dr. Dn. Juan Antonio Agüero Pedrosa, Presvitero Visitador Eccl ${ }^{o}$ de esta Ciud. y obispado de Valld. y Scrio. del Santo Oficio de la Ynqqon. de ella, sección Inquisición 1135, exp. 11.

${ }^{15}$ Demerson, P. y J. «La Sociedad Económica de Amigos del País de Ciudad Rodrigo». Cuadernos de historia moderna y contemporánea 3: 43 y 44. Los estatutos de la misma fueron publicados en Madrid en 1782, en la imprenta de Antonio de Sancha.

${ }^{16}$ Archivo de la Real Academia de la Historia, secretaría, expediente personal de Simón Rodríguez Laso.

${ }^{17}$ Archivo de la Real Academia de Bellas Artes de San Fernando, leg. 40-5/1. 
la junta general de 5 de enero de 1783 (Madrid, imprenta Joachin Ibarra, 1783), que son mencionadas como impresos. ${ }^{18}$

\section{Rector del COLEGio DE EsPaÑa}

Cuando Laso consiguió su plaza como colegial en Bolonia, pasó a formar parte de una de las instituciones más representativas de España en Italia. La fundación albornociana llevaba en el siglo XVIII más de cuatro centurias incardinada en la universidad boloñesa. En 1364, el cardenal don Gil de Albornoz, arzobispo que había sido de Toledo y encargado de reconquistar los Estados Pontificios por el Papa Clemente VI, creó un Colegio para estudiantes españoles en la ciudad de Bolonia. Lo fundó no sólo para estudiantes castellanos, sino para todos aquellos que procediesen de las tierras hispanas, fueran del reino que fuesen. Surgía así el primer colegio mayor hispano y bajo su influencia se crearon el resto de los peninsulares años más tarde.

El prelado fundador dotó a la fundación de bienes y dejó como legado su biblioteca y sus códices. El Colegio de San Clemente fue puesto desde sus orígenes bajo la protección del Papa y luego, del Rey de Castilla, cuando lo visitó Carlos V con motivo de su coronación imperial. ${ }^{19}$

Lo dirigía un rector, elegido democráticamente cada $1^{\circ}$ de mayo entre los colegiales. En sus tareas de gobierno era ayudado por algunos de los residentes llamados consiliarios, nombrados también entre la colegiatura. ${ }^{20}$ Un capellán, ajeno al cuerpo colegial, y un ecónomo, completaban el personal de la Casa. Todo ello quedaba reflejado en unos estatutos reformados varias veces a lo largo de los siglos. ${ }^{21}$

${ }^{18}$ Aguilar Piñal, F. 1993. Bibliografía de autores españoles del siglo XVIII, tomo VII: 253. Madrid: Instituto Miguel de Cervantes del CSIC.

${ }^{19}$ Es abundante la bibliografía en torno al Real Colegio de España, especialmente en lo que se refiere a sus orígenes, fundación y primeros siglos. La época contemporánea, en cambio, está especialmente poco estudiada. La principal obra para conocer la historia de la fundación desde sus orígenes hasta finales del siglo XIX es El Colegio de Bolonia, centón de noticias relativas a la fundación hispánica de San Clemente, compuesta por los colegiales Pedro Borrajo y Herrera y Hermenegildo Giner de los Ríos (Madrid, imprenta de M. Minuesa de los Ríos, 1880). Desde 1972, dirigidos por el profesor Evelio Verdera y Tuells, se han publicado seis tomos de la llamada Studia albornotiana. El cardenal Albornoz y el Colegio de España (Zaragoza, editorial Cometa, 1972-1979), con más de 500 artículos sobre la historia del Colegio y la vida y obra de su fundador. La universidad Carlos III de Madrid acaba de publicar el libro del autor de este artículo titulado San Clemente de Bolonia (1788-1899): el fin del Antiguo Régimen en el último colegio mayor español.

${ }^{20}$ Pérez Martín, A. 1978. Tomo I: 71 y 72.

${ }^{21}$ Para conocer los estatutos, véase la obra de Berthe M. Marti The Spanish College at Bologna in the Fourteenth Century, edition and Translation of its statutes, with introduction and notes. Con 
Poco a poco el Colegio, en el que la mayoría de sus colegiales eran clérigos seculares, comenzó a decaer, pese a los privilegios, la protección de los monarcas y el aire nobiliario que había adquirido. Este declive fue ya apuntado en el siglo XVI por el Doctor Diego de Neila, antiguo colegial y rector, canónigo en Salamanca, que aducía estas razones, «la una a aver ya tanta multitud de collegios como ay en España y la otra al estar ya los linages tan mezclados y contaminados que ciertamente se hallarían pocos que tengan las qualidades que para entrar en ese insignísimo collegio se requiere». ${ }^{22}$

Autores como Dámaso de Lario, señalan que las prebendas y la facilidad para obtener cargos en la monarquía por parte de los colegiales de Bolonia era menor que para los peninsulares: los colegios mayores había proliferado en España y el de Bolonia se encontraba lejos de los centros de poder colegiales de la península. ${ }^{23}$

Para solucionar los problemas y comprobar la situación de los becarios de Bolonia, desde la segunda mitad del siglo xviII, el poder real sobre la fundación fue aumentando y el Rey de España era prácticamente la máxima autoridad que regía el Colegio. Un hecho clave en este proceso tuvo lugar en 1757, con la visita del canónigo Francisco Pérez Bayer, que años más tarde comenzó la reforma los colegios mayores de la península. Bayer cambió por completo las estructuras del Colegio y la vida colegial. A partir de aquel momento el Rey era quien nombraba al rector por tiempo indefinido entre los que habían sido colegiales. ${ }^{24}$

La visita fue solicitada al secretario de Estado, Ricardo Wall, por los colegiales ante el desorden y el desbarajuste que provocaba la elección de cargos y el deterioro de la vida colegial, muy alejada del proyecto fundacional. El primer rector designado por el Rey fue Antonio Martínez Pons (1758-1769). A él le siguieron, todos con carácter interino, Joaquín Quintano (1769-1775), Luis de Urriola (1775-1781) y Juan José de Alfranca y Castellote al que sucedió Laso. ${ }^{25}$

Cuando Simón tomó posesión, se hizo cargo de un centro que llevaba en crisis varios siglos. Las dificultades por las que atravesaba provenían de la

anterioridad, en 1858, fueron publicados por el padre Beltrán de Heredia bajo el título «Los primeros Estatutos del Colegio Español de San Clemente en Bolonia,» Hispania Sacra 11: 187-224 y 409-426.

${ }^{22}$ Esta documentación fue publicada en 1979 por Baltasar Cuart Moner en «Diego de Neila, colegial de Bolonia, canónigo de Salamanca y amigo de Juan Ginés de Sepúlveda», en Verdera y Tuells, E. (ed.): Tomo VI: 309.

${ }^{23}$ Lario Ramírez, D de. 1979. «El Colegio de San Clemente de Bolonia durante la impermeabilización hasburguesa (1568-1659)», en Verdera y Tuells, E. (ed.): Tomo IV: 168.

${ }^{24}$ Sobre esta visita véase Nieto Sánchez, C. 2011. «Un capítulo inédito de la reforma de los colegios mayores universitarios: la visita de Pérez Bayer a los colegios españoles en Bolonia». Revista de investigaciones históricas 31: 93-114.

${ }^{25}$ Pérez Martín, A. 1979. Tomo IV: 2121-2125. 
misma constitución del Colegio, una institución medieval creada en momentos de sumisión de la cultura civil a la eclesiástica. La fundación seguía manteniéndose viva pese a que los colegios mayores hispánicos, creados todos al amparo de sus constituciones, se encontraban a punto de desaparecer y contaba, sin duda, con el apoyo de la Corte de España. Este hecho tenía una lógica: algunos de los familiares de los que luego serían los promotores de la reforma de los colegios de Valladolid, Salamanca y Alcalá de Henares, residían en el Colegio. Campomanes consiguió una plaza dispensando de edad a su sobrino, Domingo Fernández de Campomanes. Lo mismo hizo años más tarde el conde de Floridablanca para su sobrino. ${ }^{26}$

Pese a la crisis, el Colegio estaba bastante integrado en la sociedad boloñesa y había incrementado notablemente su nivel cultural, gracias, en parte, a la labor realizada por el rector Alfranca, que había puesto en marcha un plan de estudios innovador patrocinado por la Corte de Madrid. ${ }^{27}$ Alfranca dejará el rectorado de Bolonia al ser nombrado alcalde del Crimen en la Audiencia de Sevilla en 1787. Su sucesor fue Simón Rodríguez Laso.

A principios de octubre de 1787, la primera secretaría de Estado se había fijado en Laso para el rectorado de Bolonia. Una escueta minuta conservada en el archivo del Ministerio de Asuntos Exteriores de Madrid dice así:

«El Rey tiene ya provisto el rectorado. Avísese a Dn. Simon Laso, Dignidad de Ciudad Rodrigo si quiere ir a este rectorado a que S. M. piensa destinar con retención de su Digdad. a la que añadiría el Rey algún aumento de dotación en rta. eccla». ${ }^{28}$

El día 12 de noviembre Laso escribía al conde de Floridablanca aceptando el nombramiento de rector. ${ }^{29}$ Pero, ¿por qué fue elegido Laso entre sus compa-

\footnotetext{
${ }^{26}$ En 1774, Moñino, agraciado meses antes con el condado de Floridablanca por Carlos III, embajador ante el Papa Clemente XIV, escribió al secretario de Estado solicitándole que intercediera ante el monarca para que dispensara a su sobrino, Antonio José Salinas y Moñino, del requisito de tener 21 años cumplidos para ser colegial de San Clemente. El Rey accedió a su petición y Salinas y Moñino fue admitido como colegial por el rector Quintano. Archivo General de Simancas, Al Col ${ }^{\circ}$. Rl. y mayor de Sn. Clemente delos Españoles de Bolonia, El Pardo, Madrid, $1^{\circ}$ de marzo de 1774, secc. Estado, leg. 4746.

${ }^{27} \mathrm{El}$ padre Batllori ha estudiado detenidamente las modificaciones introducidas por el nuevo plan de estudios en el artículo «El Colegio de España a finales del siglo XVIII», en Verdera y Tuells, E. (ed.): Tomo II: 639-669. 1972. El plan de estudios completo se encuentra en el legajo 4747 de la sección de Estado del archivo General de Simancas.

${ }^{28}$ AMAE, minuta avisando del nombramiento de Rector a Simón Rodríguez Laso, 18 de octubre de 1787, leg. P-822, exp. 11601.

${ }^{29}$ AMAE, Simón Rodríguez Laso al conde de Floridablanca, Ciudad Rodrigo, Salamanca, 12 de noviembre de 1787, leg. P-822, exp. 11601. Floridablanca recibiría sendas cartas de agradecimiento por el nombramiento, entre ellas las del obispo de Ciudad Rodrigo, fray Benito Uría y Valdés (17 de febrero
} 
ñeros, todos ellos antiguos colegiales y por tanto elegibles? Astorgano afirma en el estudio crítico del Diario en el Viage de Francia e Italia, que su labor en la Sociedad Económica fue eficaz y debió ser el «trampolín» para el rectorado de San Clemente en Bolonia. ${ }^{30}$ El padre Manuel Luengo, ${ }^{31}$ ex jesuita español residente en Bolonia, en cambio, aduce en su Diario un motivo muy claro para que lo eligieran. La Corte tanteó a varios candidatos, pero todos ellos pusieron una condición para aceptar aquel cargo: que el Colegio prescindiera de los colegiales que había en aquel momento, quedando vacío, y fuera «repoblado» por nuevos estudiantes españoles. Sólo así se podría «quitar sin contradicción todas las cosas que desagradan, e introducir todas las que pareciesen justas». ${ }^{32}$

Laso aceptó el cargo sin poner esta condición y fue designado rector. No puede olvidarse además un detalle que pudo pesar en su elección: uno de los colegiales, que convivió con Laso en Bolonia y conocía sus cualidades era Antonio José Salinas y Moñino, sobrino de Floridablanca.

Para que Laso pudiera «servir en dicho empleo con la utilidad y esplendor del Colegio y sus alumnos», el Rey le confirió las facultades de visitador apostólico y delegado regio, limitadas a la enmienda, reforma o mejora de las reglas de la Casa, tanto en lo referente a los estudios, que era su principal objetivo, como en el ramo económico. Sólo tomaría por sí mismo las disposiciones urgentes, teniendo que consultar el resto directamente al secretario de Estado. El Colegio quedaba bajo el control del gobierno de Madrid ejercido a través de la secretaría de Estado.

Entre tanto, el nuevo rector haría debía cuidar con especial celo que se cumpliesen las últimas disposiciones reales, principalmente las referentes al plan de estudios, puesto en marcha por su predecesor. Debía preocuparse por el decoro

de 1788), y del deán y cabildo de la catedral de Ciudad Rodrigo (22 de febrero de 1788). En AMAE, expediente personal de Simón Rodríguez Laso, leg. P-822, exp. 11601.

${ }^{30}$ Rodríguez Laso, N. 2006: 91.

${ }^{31}$ El Diario del padre Luengo, compuesto por un total de 63 tomos y conservado en el archivo del santuario de Loyola, es un testimonio imprescindible para reconstruir la vida del Colegio de San Clemente de los españoles a finales del siglo XviII. Su autor, Manuel Nicolás Luengo Rodríguez (17351816), uno de los muchos jesuitas españoles expulsos establecidos en Italia, permaneció en Bolonia desde el extrañamiento de la Compañía hasta el año 1798. La obra de Luengo ha sido estudiada por Inmaculada Fernández Arrillaga, autora de Memorias de un exilio. Diario de la expulsión de los jesuitas de los dominios del Rey de España (1767-1768). Manuel Luengo, S. I., Alicante, San Vicente de Raspeig-Publicaciones de la Universidad de Alicante, 2002 y El retorno de un jesuita desterrado. Viaje del padre Luengo desde Bolonia a Nava del Rey (1798), Alicante, San Vicente de Raspeig-Publicaciones de la Universidad de Alicante, 2004. Esta misma autora ha recogido en la obra El legado del P. Manuel Luengo. S. I. (Alicante, Instituto de Cultura Juan Gil-Albert 2003) los índices completos del Diario. Su biografía puede consultarse en O'Neill, C. E y Domínguez, J. M. 2001. Diccionario histórico de la Compañía de Jesús: tomo III, 2437. Madrid: Universidad Pontificia de Comillas.

${ }^{32}$ ASL, Diario del padre Manuel Luengo, tomo XXII, p. 448. 
de los colegiales, que no podían contraer deudas ni distraerse en cosas que no fueran de importancia. Encargaba el Rey que tuviese una buena correspondencia con las dignidades episcopales de Bolonia, el cardenal legado y el arzobispo de la ciudad, usando moderadamente los privilegios y franquicias, evitando abusos en materias económicas y en la protección de patentados y delincuentes que pudiesen refugiarse en el Colegio y no merecieran asilo.

Por último, Floridablanca, por orden del Rey, animaba a Simón Laso a que tratara con estimación, moderación y agrado a los jóvenes, excusando en lo posible innovaciones que no produjeran utilidad y evitando daños dignos de remedio. ${ }^{33}$

El nuevo rector, que seguía conservando la dignidad de maestrescuela de Ciudad Rodrigo, recibiría 15.000 reales de vellón como pensión anual sobre la Mitra de Córdoba. ${ }^{34} \mathrm{La}$ asignación en virtud de su cargo de rector quedó fijada en 9.000 reales de vellón al año. ${ }^{35}$

Simón Laso y su hermano, el inquisidor Nicolás Rodríguez Laso, emprendieron viaje a Bolonia partiendo de Barcelona el 15 de mayo de 1788, acompañados por un criado, Vicente de Arcinaga. El viaje de estos dos clérigos ilustrados, como en el de otros españoles como Ponz o Moratín, tenía como objetivo conocer las realidades económicas, sociales, artísticas y religiosas de los países de Europa. Después de un largo periplo y tras conocer Lyon, París, Turín o Parma, los Laso llegaron a Bolonia el día 9 de agosto de $1788 .{ }^{36}$ Les recibieron el rector saliente, Juan José de Alfranca y Castellote, y los colegiales que residían allí: Fernando Queipo de Llano, ${ }^{37}$ hijo del conde de Toreno; Wenceslao Argumosa, Rodrigo Sierra y Tomás Arias de Leiza. El día 15, festividad de la Asunción, el rector tomó posesión de su cargo en un acto solemne que con profusión de detalles describe su hermano en su Diario. Se celebró un Te Deum en la iglesia de la Annunziata. La comitiva partió del Colegio con una larga procesión formada por 26 carrozas. En la iglesia, el rector se sentó en el presbiterio, en el lado del Evangelio, con sitial, silla y almohada para arrodillarse. En un ambiente festivo

${ }^{33}$ AMAE, el conde de Floridablanca a Simón Rodríguez Laso, Aranjuez, Madrid, 15 de abril de 1788, leg. P- 822, exp. 11601.

${ }^{34}$ AMAE, el conde de Floridablanca al secretario de Despacho de Estado, Madrid, 4 de julio de 1788, leg. P- 822, exp. 11601.

${ }^{35}$ AMAE, Simón Rodríguez Laso al conde de Floridablanca, Bolonia, 8 de noviembre de 1789, leg. P- 822, exp. 11601.

${ }^{36}$ Todo el viaje está perfectamente descrito y estudiado en la obra mencionada en la nota 2.

${ }^{37}$ Queipo acompañó al hermano del rector en su viaje tras dejar Bolonia. El Rey dispensó al colegial para volver a Bolonia debido a su mal estado de salud, por lo que no completó su estancia en la fundación albornociana. En AMAE, el conde de Floridablanca a José Nicolás de Azara, Madrid, 10 de febrero de 1789, leg. SS 238. 
se celebró después un «refresco» en el cortile del Colegio, con gran alegría de los presentes y de los colegiales. ${ }^{38}$

Frente a la visión perfectamente idílica de la toma de posesión de Simón Laso que ofrece su hermano, el padre Luengo cuenta los hechos de una forma algo distinta: afirma en su Diario que «disgustó mucho a los señores colegiales el pensamiento de la Corte de Madrid de enviarles un señor canónigo, de España, que fuese su Rector» y relata las gestiones realizadas por la Corte para buscar un sustituto de Alfranca: Floridablanca tanteó a varios antiguos colegiales. Cita Luengo a dos «un señor Quintano, que fue por mucho tiempo Colegial y Rector en este Colegio de San Clemente, y ahora es tesorero en la Catedral de Cuenca (...) y don Jacinto Miranda ${ }^{39}$ y acaso alguno otro más», ${ }^{40}$ pero ambos se excusaron y no quisieron aceptar.

Según Luengo, «este mismo día se puede decir que empezó la reforma en el Colegio, habiendo convidado el nuevo rector al refresco y conversación por la noche a toda la nobleza de la ciudad, pero expresando solamente a los hombres, y excusándose de hacer lo mismo con las señoras, por ser fiesta suya propia y ser un eclesiástico. Se esperan otras muchas determinaciones, que irá tomando suavemente y poco a poco el nuevo Rector, a lo que él mismo ha insinuado, y arreglándose a las instrucciones que trae de Madrid y escritas de puño y letra del Secretario de Estado, D. José Moñino». ${ }^{41}$

Las relaciones de Laso con el gobierno de Madrid debieron ser francamente buenas. ${ }^{42}$ Luengo afirma varias veces en su Diario que esas buenas relaciones permitían la subsistencia del Colegio, protegido por los diferentes secretarios de Estado, cuya conducta con respecto a los colegios mayores peninsulares fue diferente. Estos

\footnotetext{
${ }^{38}$ Rodríguez Laso, N. 2006: 305 y 306.

${ }^{39}$ Es de suponer que Luengo se refiere a Jacinto Díaz Miranda, cantor de la catedral de Oviedo, admitido por el rector Quintano y cuya permanencia en el Colegio está documentada entre 1773 y 1779. Su biografía ha sido realizada por Luis Gil bajo el título «Jacinto Díaz Miranda, colegial de San Clemente y traductor de Marco Aurelio», en Verdera y Tuells, E. (ed.): Tomo V: 563-582. 1979.

${ }^{40}$ Según la documentación custodiada en el archivo del Ministerio de Asuntos Exteriores, junto con los mencionados candidatos otro antiguo colegial, Cayetano Moreno de Simón Pontero, se ofreció voluntariamente para ocupar el cargo de rector. Pontero, sabedor de la marcha de Alfranca, escribió al conde Floridablanca solicitando la plaza de rector por el ser el decano de los colegiales y para poder completar su instrucción en Bolonia, pero su candidatura no fue aceptada, tal y como se dice en la propia nota manuscrita por el secretario de Estado sobre su carta. AMAE, Cayetano Moreno de Simón Pontero al conde de Floridablanca, Granada, 18 de octubre de 1787, leg. P-822, exp. 11601.

${ }^{41}$ ASL, Diario del padre Luengo, tomo XXII, pp. 448-449.

${ }^{42}$ En la sección de Estado del archivo General de Simancas se conserva una abundante correspondencia entre los diferentes secretarios de Estado y el rector. En todas sus misivas, la mayoría de ellas protocolarias y que aportan pocos datos a la investigación, Laso se afana en mantener una buena relación con la Corte de Madrid y con sus superiores. Toda esta correspondencia se contiene en el legajo 4748 de la sección de Estado.
} 
ministros se encargaban de disimular los abusos y las faltas del de Bolonia y entre todos ellos destacaba el conde de Floridablanca, a quien el rector Laso «le debe muchos favores y de quien depende por razón de las cosas del Colegio». ${ }^{43}$

El largo rectorado de Laso, fue sin duda uno de los más convulsos de la historia de la fundación. Le tocó vivir el paso del Antiguo Régimen al Estado Liberal, en un territorio, la península itálica, donde este tránsito estuvo muy marcado por la presencia y ocupación francesa de los Estados Pontificios. No es difícil imaginar que la fundación fuera un flanco fácil para el gobierno satélite de Francia instalado en Bolonia: el Colegio había nacido en una sociedad regida por el privilegio y gracias a ellos se mantenía. Así, se pueden distinguir varias etapas en la estancia de Laso en Italia y su rectorado. En la primera, tras un cierto repunte cultural, hubo un enfrentamiento con la República Cisalpina. En la segunda, época de distensión, el Colegio albergó a huéspedes ilustres. En la tercera y última, fue clausurado y vuelto a abrir.

LA LUCHA POR LOS PRIVILEGIOS. EL ENFRENTAMIENTO DE LASO CON LA REPÚBLICA CISALPINA

Los primeros años del rectorado de Simón Laso fueron parecidos a los de su predecesor. El Colegio vivió en los últimos tiempos del reinado de Carlos III y los primeros de Carlos IV un cierto florecimiento. En octubre de 1789 se celebró con gran boato en la vecina iglesia de San Pablo la ascensión al trono de Carlos IV, en contraste con los humildes funerales celebrados en enero por el alma del Rey Carlos III. ${ }^{44}$ En la misa pontifical en honor del nuevo monarca, el cardenal Gioannetti, arzobispo de Bolonia, impuso solemnemente al rector la insignia de la Orden de Carlos III, concedida poco antes ${ }^{45}$ a solicitud del propio Laso. ${ }^{46}$

${ }^{43}$ ASL, Diario del Padre Luengo, tomo XXIII, p. 149.

${ }^{44}$ Primo Bertrán Roigé califica estos funerales como los menos solemnes de todos los celebrados por los reyes de España en la historia del Colegio, debido a la crisis económica que atravesaba la fundación, siendo decisión del propio Laso el comedimiento económico en lo relativo al oficio fúnebre. Véase «Ceremonias fúnebres por los monarcas españoles», en Verdera y Tuells, E. (ed.): Tomo V: 4169. 1979. Luengo también describe en su Diario de forma pormenorizada estos funerales y la pobreza de los mismos. Según el ex jesuita los actos fúnebres se limitaron a «una Misa cantada privadamente por los Capellanes del Colegio, poniendo un paño negro en el pavimento de la Iglesia y 6 u 8 hachas alrededor». Toda la descripción pormenorizada de la actitud del Colegio tras la muerte del Rey Carlos III, puede verse en el tomo XXIII del Diario, p. 564 y ss.

${ }^{45}$ ASL, Diario del padre Luengo, tomo XXIII, pp. 563 y 564. La concesión de la cruz se produjo el 14 de septiembre de 1789. El expediente de la concesión se conserva en el archivo Histórico Nacional, orden de Carlos III, expediente 348.

${ }^{46}$ Seis meses después de tomar posesión de su nuevo cargo, Simón Laso escribió a Floridablanca solicitando que interviniera ante el Rey para que le fuera concedida la cruz de de la Orden de Carlos

Hispania Sacra, LXV

131, enero-junio 2013, 275-308, ISSN: 0018-215-X, doi: 10.3989/hs.2013.009 
Durante estos primeros años, según la documentación conservada en el archivo General de Simancas, Laso intentó ser agraciado, sin éxito, con la distinción de Sumiller de Cortina ${ }^{47}$ reservada a eclesiásticos distinguidos. ${ }^{48}$

Aquellos años de renovación cultural y académica fueron también de gran penuria económica. El rector tuvo que socorrer al Colegio en varias ocasiones. En 1789 prestó a la institución 9.000 reales y cedió otros 4.000 a fondo perdido. Además renunció a los 12.000 reales que le entregó la Corte de España por su viaje. ${ }^{49}$ Un año más tarde volvió a aportar 7.500 libras de su propio peculio. ${ }^{50} \mathrm{En}$ 1814, según el testimonio del mayordomo del Colegio, Santiago Galvani, Laso había gastado «de su bolsillo» la considerable suma de 11.000 pesetas, es decir 44.000 reales de vellón, «sin haber tomado ni querido la menor reintegración». ${ }^{51}$ El mismo dependiente ponderaba la labor del rector para mejorar la economía y las rentas, pues al nada más llegar a Bolonia había satisfecho las deudas contraídas, había adquirido varios predios rústicos y había aumentado las rentas en más de 9.000 pesetas. $^{52}$

El rector continuó en sus primeros años con la renovación cultural trazada por su predecesor. En 1786, Alfranca había determinado que el Colegio albergara actos culturales públicos, las disertaciones, que sirvieran como estímulo para los residentes en sus trabajos personales y de prueba externa para demostrar que reinaba un ambiente de estudios.

III. Decía al secretario de Estado que «...como es considerado en esta brillante y populosa Ciudad el empleo de Rector de este Rl. Colegio, por la protección que goza de nuestros Augustos Soberanos, conocerá bien quanto esplendor se le añadiría si en prueba de esta protección se dignara $S$. M. honrarme con la Cruz de la Rl. distinguida Orden de Carlos III». AGS, Simón Rodríguez Laso al conde de Floridablanca, Bolonia, 14 de febrero de 1789, secc. Estado, leg. 4747.

${ }^{47}$ Covarrubias en su Tesoro de la lengua castellana, habla así del Sumiller de Cortina: «Los reyes acostumbran a tener en sus capillas y en las iglesias donde oyen los oficios divinos unas camas debajo de las cuales les ponen las sillas y sitiales; y porque se corre una de las cortinas cuando entra o sale el Rey o se hace alguna ceremonia como la confesión o la paz y las demás, el que tienen el oficio de correr la cortina se llama sumiller de cortina, término alemán, al uso de la Casa de Borgona». Covarrubias de Orozco, S. 1995. Tesoro de la lengua castellana o española: 360. Madrid: Castalia, 1995.

${ }^{48}$ AGS, Simón Rodríguez Laso al cardenal-patriarca de las Indias, Bolonia, 22 de abril de 1791 y Simón Rodríguez Laso al conde de Floridablanca, Bolonia, 30 de abril de 1791, secc. Estado, leg. 4748.

${ }^{49}$ AMAE, certificación de Tomás Arias de Leyza, secretario, Bolonia, 25 de noviembre de 1789 , leg. P-822, exp. 11601.

${ }^{50}$ AMAE, certificación de Juan José de la Madrid, secretario, Bolonia, 14 de diciembre de 1790 , leg. P-822, exp. 11601.

${ }^{51}$ AMAE, Extracto, traducción y notas de los documentos relativos a la suspensión del Rl. Colegio mayor de Sn. Clemente de los Españoles fundado en Bolonia por el Emmo. Sor. Cardenal Dn. Gil de Albornoz desde el año 1365, fol. 6 vto., leg. P-822. exp. 11601.

${ }^{52}$ Ibídem. fols. 8 y 8 vto. 
La Corte dio el visto bueno para que el rector Laso continuase con el plan de estudios y se retomasen los ejercicios literarios. ${ }^{53}$ Desde 1788 a 1796, estando Bolonia ocupada por Bonaparte, prevalecieron los temas jurídicos y económicos en las disertaciones colegiales. Todos están recogidos en el Libro de asiento de los exercicios del Colegio, que estará a cargo del colegial bibliotecario que por tiempo fuere, conservado en el archivo del Real Colegio. Este libro es una fuente de incalculable valor para apreciar las corrientes de pensamiento y de cultura que predominaban en aquellos colegiales, laicos y eclesiásticos. De los ejercicios desarrollados durante el año 1794 da cuenta Leandro Fernández de Moratín en su Diario. Moratín, que permaneció en Bolonia entre 1793 y 1796,,$^{54}$ fue amigo de los colegiales y tuvo relación con Laso, al que dedicó un poema, Epístola a Don Simón Rodríguez Laso, ${ }^{55}$ y en sus escritos habla de las clases suplementarias para completar la formación de los colegiales a las que asistió, concretamente a las de inglés. ${ }^{56}$

Hasta la ocupación francesa que truncó la vida académica del Colegio, se catalogó la biblioteca y el archivo. El reorganizador fue el becario Juan Tineo. El colegial encargado de la elaboración del Liber de Rebus Gestis ${ }^{57}$ dice que este trabajo «desde que llegó el Rector se había empezado». ${ }^{58}$

Pero el ambiente cultural predominante en los primeros tiempos de Laso en Bolonia acabó pronto en una institución que pasó por graves dificultades. La Revolución Francesa y los triunfos militares de Napoleón en el norte de Italia acabaron con el Antiguo Régimen en la península itálica. En marzo de 1796, por orden del Directorio francés, las tropas del joven Napoleón Bonaparte salieron de París en dirección a Italia. En un rápido avance derrotaron a los ejércitos austriacos y sardos. El día 19 llegó a Bolonia el general Bonaparte y acabó con la Legacía Papal, despidiendo al cardenal legado, monseñor Vincenzi. Napoleón se presentó ante el Senado proclamando que Bolonia era una ciudad liberada del

\footnotetext{
${ }^{53}$ ARCE, el conde de Floridablanca a Simón Rodríguez Laso, Madrid, 4 de octubre de 1791, leg. Cartas varias $1, \mathrm{n}^{\circ} 15$.

${ }^{54}$ Para conocer la relación de Moratín con el Colegio resulta de gran interés el artículo de Belén Tejerina, «Leandro Fernández de Moratín y el Colegio de España», en Verdera y Tuells, E. (ed.): Tomo VI: 623-650. 1979.

${ }^{55}$ Fernández de Moratín, N. y L. 2008. Obras Completas, tomo II: 784 y ss. Navarra: Cátedra.

${ }^{56}$ Ibídem, tomo I: 899-900 y 902.

${ }^{57}$ El llamado Liber de Rebus Gestis recoge los acontecimientos y hechos más sobresalientes de la vida del Colegio. Su verdadero título es Epítome chronologico de los casos más notables sucedidos en este Colegio. Consta de tres volúmenes, comenzando el primero de ellos en 1364. Era redactado por el colegial llamado «historiador». Dejó de realizarse en el año 1808.

${ }^{58}$ ARCE, Liber de Rebus Gestis II, fol. 350 vto.
} 
poder pontificio y advirtió a los senadores locales de la obligación de jurar ante él mismo fidelidad a la República Francesa. ${ }^{59}$

En 1797, Napoleón creaba en el norte de Italia la llamada República Cisalpina con capital en Milán. Dentro de sus límites quedó la ciudad de Bolonia. El gobierno se negó desde el principio a reconocer ningún tipo de inmunidad a la fundación albornociana, pues sus franquicias eran contrarias a los principios de la libertad y la igualdad de todos los hombres. Comenzó así un proceso de negociaciones con varios vértices. El embajador del Rey de España ante el Papa, José Nicolás de Azara ${ }^{60}$ tenía órdenes expresas del primer ministro Godoy para ayudar en la medida de sus posibilidades al Colegio. En Francia, el embajador de España intervino ante el ministro Tayllerand para salvaguardar las exenciones de la fundación. ${ }^{61}$ Azara negoció con la República Cisalpina durante el último cuatrimestre de 1797 y principios de 1798.

El día 8 de julio de 1797, la Junta de Contribuciones boloñesa envió una nota al rector Laso, dándole a entender que en la ciudad no debía haber casas ni personas con exenciones o privilegios. El presidente de la Junta, Vincenzo Zambeccari, le advertía que todo privilegio era incompatible con el nuevo sistema político, ya que la sociedad debía mirar a cada individuo de manera igualitaria sin distinción alguna y argumentaba que «sulle ruine delle aristocratiche gererchie s'inalzò l'edifizio della democratica eguaglianza». ${ }^{62}$

Tres días después, Rodríguez Laso contestaba a Zambeccari extrañado, pues pensaba que había demostrado su acatamiento con su actitud tolerante hacia el nuevo gobierno. ${ }^{63}$ Escribió también al primer ministro español pidiéndole ayuda. Laso le comunicaba la idea del gobierno de la ciudad sobre las exenciones del establecimiento, que pretendían suprimir, pese a no tener la institución

\footnotetext{
${ }^{59}$ Varni, A. 1973. Bologna Napoleonica: VI y VII. Bolonia: Massimiliano Boni.

${ }^{60}$ José Nicolás de Azara nació en Barbuñales, Huesca, en 1730. En Huesca y Salamanca —ciudad en la que fue colegial del colegio mayor de San Salvador de Oviedo- estudió literatura, entrando pronto en el servicio diplomático de la monarquía. Fue enviado a Roma, donde permaneció más de treinta años como procurador general y más tarde como embajador. Tuvo una activa participación en la recepción de los jesuitas expulsados de España que llegaban a Roma. En 1798 fue nombrado embajador de España en París. Fue hombre ilustrado, consejero de embajadores, nobles y monarcas europeos y mecenas del arte, especialmente del pintor Mengs. Era tío del colegial Eusebio Bardají y Azara y visitó el Colegio en 1790. Falleció en París en 1804. Para acercarse a su biografía, pueden consultarse las obras de Castellanos de Losada, B. S. 1850. Biografía del célebre diplomático y distinguido literato español D. José Nicolás de Azara y Perera. Madrid: D. G. González y Corona y Baratech, C. E. 1948. José Nicolás de Azara. Zaragoza: Institución Fernando el Católico.

${ }^{61}$ AMAE, el marqués del Campo a Manuel Godoy, París, 10 de noviembre de 1797, leg. H 4321.

${ }^{62}$ AMAE, Vincenzo Zambeccari a Simón Rodríguez Laso, Bolonia, 8 de julio de 1797, leg. H 4321.

${ }^{63}$ AMAE, Simón Rodríguez Laso a Vincenzo Zambeccari, Bolonia, 11 de julio de 1797, leg. H 4321 .
} 
influencia alguna ni voto activo o pasivo en el gobierno de Bolonia y depender en todo de sus bienes. ${ }^{64}$

A finales de 1787, el Directorio volvió a preocuparse del Colegio de España. El ministro para los Asuntos Exteriores, Carlo Testi, solicitó a la administración de Reno que pidiese al rector una relación de los privilegios, para estar informado de cuáles eran aquellos «che incomodano la codesta municipalità per combinare quali sono e quali non sono compatibili col nvo. sistema». ${ }^{65}$

Siguiendo las órdenes de su superior, la administración de Reno escribió al rector para que le enviase una copia de los privilegios, franquezas y exenciones «di quali è stato in addietro infignito il Reale Collegio, a cui degnamente presiede». En el archivo del Ministerio de Asuntos Exteriores se conserva la copia del informe realizado por el rector sobre las inmunidades. Laso definía el Colegio como «Casa Ministeriale con le distinzioni e prerogative di queste». Estos eran sus privilegios: jurisdicción sobre los colegiales y el personal y autorización del monarca para actuar como delegado regio y visitador apostólico. Junto a ellos mencionaba otros dos menores: la exención de impuestos sobre los bienes producidos por sus propias tierras, exceptuando el Dazio delle porte ${ }^{66} \mathrm{y}$ una «ben discreta» por el uso del molino, y el poder realizar su propia matanza de reses bovinas, para el consumo privado del rector y colegiales. ${ }^{67}$

Analizados los privilegios, el embajador de España en Roma recibió la resolución: Testi le comunicaba que el Colegio podría tener sobre sus puertas principales las armas del Rey de España y el rector, los colegiales y asistentes del Colegio, podían seguir luciendo los símbolos nacionales españoles. ${ }^{68}$ En cambio, el Directorio político, después de haber examinado los privilegios y exen-

${ }^{64}$ AMAE, Simón Rodríguez Laso a Manuel Godoy, Bolonia, 14 de julio de 1797, leg. H 4321.

${ }^{65}$ AMAE, Carlo Testi al administrador central de Reno, Milán, 19 de frimario de año VI republicano (9 de diciembre de 1797), leg. SS 368.

${ }^{66} \mathrm{El}$ «Dazio delle porte» o «Dazio sulle porte» era un impuesto que gravaba los productos que entraban en la ciudad de Bolonia. Estaba vigente desde el año 1116, aunque su máximo desarrollo se produjo entre el siglo XVI y finales del siglo XVIII. Era aplicado a las mercancías portadas por forasteros y por ciudadanos de la propia ciudad de Bolonia y estaba destinado a ser empleado en exigencias particulares como guerras, carestías y obras de interés público. En Guida generale degli Archivi di Stato italiani, tomo I: 594. Roma. 1981.

${ }^{67}$ AMAE, Informe sobre los privilegios y exenciones del Real Colegio de San Clemente hecho por los Sres. D. Simón Rodríguez Laso y D. Giovanni Tineo, Segretario, Bolonia, sin lugar ni fecha, leg. H 4321.

${ }^{68}$ La República Cisalpina prohibió de forma efectiva que los cónsules o representantes diplomáticos de misiones extranjeras utilizasen sus enseñas nacionales o vistiesen según la costumbre de sus países de origen si no habían sido reconocidas de manera formal sus credenciales. Solamente podrían alzar banderas y llevar prendido el escudo nacional aquellos a quienes se les hubiera autorizado de forma expresa. Bando del Comisario del Poder ejecutivo ante el Departamento del Po inferior, Ferrara, 18 de nevoso del año VI republicano (7 de enero de 1798), en AMAE, leg. SS 368.

Hispania Sacra, LXV

131, enero-junio 2013, 275-308, ISSN: 0018-215-X, doi: 10.3989/hs.2013.009 
ciones, había concluido que eran contrarios al principio de igualdad reflejado en la Constitución. Los privilegios de inmunidad, asilo y exención de impuestos, así como el hecho de tener una jurisdicción diferente a la del país en la que se hallaba, eran incompatibles con el nuevo régimen. Sobre los privilegios eclesiásticos y de patronato, no podía el gobierno, subrayaba que por el momento, determinar cosa alguna, dependiendo de las disposiciones generales ${ }^{69}$ Pese a las noticias, Laso se afanó a principios de mayo de 1798 en conseguir el dinero necesario para pagar los tributos que le fuesen solicitados. Del hecho deja constancia el padre Luengo, en su Diario con estas palabras:

«La gran amistad y alianza de la Corte de Madrid con la República francesa no basta para que sea tratado con respeto este antiquísimo y privilegiadísimo Colegio de españoles, de título de San Clemente. Ayer estando yo con el Reverendo Don Simón Rodríguez Laso, se le hizo saber una orden de este gobierno por el cual se piden los mismos tributos que a los demás que tienen haciendas, o a lo menos algunos y sólo piensa en preparar el dinero para pagarles, pues Azara, preguntado por el mismo Rector cuando estuvo en el Colegio, qué había de hacer en este caso que ya se veía inevitable, le respondió que pagase todo lo que le pidiesen». ${ }^{70}$

Godoy, ante tal situación, advertida y comunicada por el rector, para ahorrarse las continuas preocupaciones que le causaban los problemas de San Clemente y la preservación de sus privilegios, que no ayudaban a las relaciones sumisas de España con Francia, decidió unilateralmente levantar de Bolonia la fundación y trasladarla fuera de la República Cisalpina, después de vender sus fondos y terrenos. Dos lugares se barajaron en aquellos momentos: Roma, descartada por no estar en «situación en permanecer mucho tiempo bajo la dominación de los Papas», y Florencia. ${ }^{71}$

La excusa fue evitar que los estudiantes españoles fueran imbuidos de la ideología liberal imperante entonces en la Universidad. Godoy quiso trasladar la institución a donde «la enseñanza sea más monárquica». No podía permanecer el Colegio en una república cuyas máximas eran enteramente opuestas a la monarquía. La empresa, en palabras de Azara, requería mucho tiempo y «bastante manexo» para poder vender los bienes y sacar buen partido de ellos.

La orden real para que Azara pasara a la embajada en París, le impidió seguir con el plan de venta. Se autorizó al barón José de Cappelletti, ${ }^{72}$ representante

\footnotetext{
${ }^{69}$ AMAE, Carlo Testi a José Nicolás de Azara, Milán, 14 de Nevoso del año VI republicano (30 de diciembre de 1797), leg. SS 638.

${ }^{70}$ ASL, Diario del Padre Luengo, tomo XXXII, p. 74.

${ }^{71}$ AMAE, informe dirigido a Manuel Godoy, sin lugar ni fecha, leg. H 4321.

${ }^{72}$ Cappelletti estuvo estrechamente ligado a la vida del Colegio. Fue nombrado en 1791 representante del Rey de España en Bolonia. Estuvo encargado de pagar las pensiones de los ex jesuitas
} 
de Carlos IV en Bolonia, que había sido instruido por Azara sobre la fundación y la venta de sus propiedades. Encargaba Azara a Cappelletti esta labor porque no veía capacitado a Rodríguez Laso, «muy buen hombre, pero poco apropiado para este gran negocio»..$^{73} \mathrm{El} 1^{\mathrm{o}}$ de mayo, el barón Cappelletti notificaba al rector que estaba encargado del levantamiento y traslado del Colegio con la consiguiente venta de sus bienes. La primera instrucción recibida era unir y ver todos los «papeles antiguos» de la fundación para comunicárselo a la Secretaría de Estado. Le pedía que empezara a recopilarlos y también todo lo que considerara oportuno.$^{74} \mathrm{El}$ rector contestó el 9 de mayo acusando recibo de su carta «y enterado de su contenido estoy pronto a comunicar a V.S. las noticias que fueran necesarias coadjuvando por mi parte a vencer las dificultades que se presenten para el cumplimiento de las intenciones del Rey». ${ }^{75}$

El traslado no se llevó a cabo. Él único motivo claro es la ocupación austriaca de la ciudad del 30 de junio de 1799 al 28 de junio de 1800. Ni un solo documento, en ninguno de los archivos consultados para este punto, aporta un motivo para comprender la paralización del cambio de sede. Este es relato del cronista del Liber de Rebus Gestis sobre lo acontecido, único testimonio que puede aclarar el desenlace:

«Estos pasos se hicieron inútiles por las representaciones del Directorio de Milán contra los buenos deseos de todos los individuos de la ciudad de Bolonia que miraban este golpe como una de las cosas más sensibles. Por otra parte veía también inutilizados sus oficios nuestro Ministro de Roma con el general francés, y cansado de tantas faenas, convino en lo que representó Milán a la corte sobre la traslación del Colegio, pareciéndole que siendo expuesta la juventud a inficionarse de las ideas republicanas, era conveniente proceder a esa resolución. Nosotros [los colegiales] que veíamos de cerca que éste era un terror pánico, y que no había mejor antídoto contra dichas ideas que el de presenciar sus fatales resultados y detestables conseguencias, opinábamos diversamente. La enagenación de los bienes del Colegio sería un cahos y no le tocaría por último al Rey sino el dolor de ver deshecha esta casa como la sal en el agua (...) Al presente no hay sombra de lo que causaba tantos temores en el Colegio, mediante la variación que ha causado la dominación austriaca que tuvo en principio en esta ciudad el día 30 de junio de este año noventa y nueve». ${ }^{76}$

españoles en Italia. Sobre el personaje véase Nieto Sánchez, C. 2011. «La rappresentanza del Re di Spagna nella città di Bologna. Il barone Giussepe Cappelletti». Nobiltà 101: 243-256.

${ }^{73}$ AHN, José Nicolás de Azara a Manuel Godoy, Florencia, 17 de marzo de 1798, sección Estado, leg. 3974.

${ }^{74}$ ARCE, Josepf Cappelletti a Simón Rodríguez Laso, Bolonia, 1 de mayo de 1798, Protección y Restablecimiento I, leg. $9, \mathrm{n}^{\circ} 2$.

${ }^{75}$ ARCE, Simón Rodríguez Laso a Josepf Cappelletti, Bolonia, 9 de mayo de 1798, Protección y Restablecimiento I, leg. 9, n 3 .

${ }^{76}$ ARCE, Liber de Rebus Gestis II, fols. 295 y 295 vto.

Hispania Sacra, LXV

131, enero-junio 2013, 275-308, ISSN: 0018-215-X, doi: 10.3989/hs.2013.009 


\section{El asilo del Rector Laso al PaPA Pio VI y otros huÉSPedes ILUSTRes}

Mientras se discutían los privilegios del Colegio en Bolonia, Roma era tomada por los franceses. En enero de 1798 las tropas francesas del general Louis Alexandre Berthier entraban en la ciudad, proclamando la República Romana. Pío VI fue expulsado, confiscados sus muebles, sus vestimentas pontificales y vendida su biblioteca a un librero romano. Una obra casi contemporánea al Papa, la Historia Eclesiástica del arzobispo Amat, describe así su destierro:

«El día 20 de febrero de 1798, se le obligó a emprender viage, á pesar del rigor de la estación. Permitiósele ir a Siena, en donde hubo poco después un fuerte terremoto, por cuyo motivo pasaron a Florencia. Allí aprovechando la quietud de que gozaba en el monasterio de padres cartuxos, trataba con algunos Obispos y sabios teólogos de los trabajos de la Iglesia y de los medios de aliviarlos, o precaver su acrecentamiento; y entre otras providencias dió la de abolir varias leyes relativas a la elección de papa, mandando que despues de su muerte se le eligiese sucesor desde luego en qualquier lugar libre y seguro». ${ }^{77}$

Estas palabras reflejan bien la realidad. El Papa Braschi era huésped del Gran Duque de Toscana en Florencia, pero el 8 de marzo de 1799 llegó una carta desde París al embajador Angiolini exigiendo que instase a su señor a que en el menor plazo de tiempo posible expulsara al Pontífice de sus estados. El día 27, un oficial francés se presentó en la Cartuja donde se alojaba para apresurar la partida y fijar el itinerario: Bolonia, Parma, Turín y Francia. Al día siguiente el Papa salió de Florencia. ${ }^{78}$ Su salud era muy delicada, debiendo abandonar aquel establecimiento eclesiástico en brazos de cuatro hombres que lo colocaron en un coche, acompañándole algunos prelados y el séquito indispensable. ${ }^{79}$

Un día después, el embajador de España en Florencia avisaba al rector Laso que el Papa había iniciado su exilio y debía pasar por Bolonia camino de Parma, donde recibiría nuevas órdenes sobre su futura residencia. «Es natural que Su santidad vaya a alojarse a ese Real Colegio». Labrador no había podido dar instrucciones hasta ese momento, porque la decisión se había tomado el día anterior. Avisaba para que se tomaran las disposiciones convenientes y le pedía

${ }^{77}$ Amat, F. 1807. Tratado de la Iglesia de Jesucristo o Historia Eclesiástica, tomo XII: 58 y 59. Madrid: imprenta de Benito García y Compañía.

${ }^{78}$ Pastor, L. Von. 1953. Storia dei Papi dalla fine del Medioevo, tomo XVI: 646 Roma: Desclée \& C. editori pontifici.

${ }^{79}$ Olaechea Albistur, R. 1980. El Cardenal Lorenzana en Italia: 176. León: Institución Fray Bernardino de Sahagún de la Excma. Diputación Provincial. 
encarecidamente que el recibimiento tuviera el menor boato y la menor ostentación, pero procurando que la estancia del Papa fuera lo más cómoda posible. ${ }^{80}$

Bolonia acogió al Pontífice sin fasto alguno pero con un respeto conmovedor. La ocupación francesa no permitía manifestaciones externas pero, según relata Pietro Baldassari, la gente se agolpaba en las calles por las que pasaba la carroza papal y con gran devoción se arrodillaban pidiendo la bendición apostólica. Llegaron al Colegio el día 30 a las cinco de la tarde y el Papa ocupó una habitación amplia y con todas las comodidades.

Los dos colegiales residentes, Mier y Marco y Catalán, salieron a recibir al Pontífice a una pequeña villa cercana a Bolonia, Scarrica l'Asino, donde el Papa descansó en un convento abandonado el día anterior a su entrada en la ciudad. Le honraron y manifestaron su satisfacción por ir a alojarse en su Colegio. «E questa obbligantissima significazione di ossequio - dice monseñor Baldassari-tenne dietro il fatto, chè non che il Pontefice, ma noi tutti della sua comitiva fummo albergati con isplendida carità». En el exterior del Colegio se agolpó una multitud que quería ver y saludar a Pío VI, pero la guardia francesa se lo impidió. Música militar saludó al Papa con «alcume belle e decenti sonate». ${ }^{81}$ Dentro del Colegio, tuvo que ser llevado en brazos para subir las escaleras hasta su habitación. El cronista que ofrece este detalle afirma que ni siquiera los soldados franceses que le custodiaban pudieron contener las lágrimas ante esa escena. ${ }^{82}$

Para la reconstrucción de la visita del Papa al Colegio no hay el testimonio de primera mano del padre Luengo, pues se encontraba en España aprovechando el decreto promulgado por Carlos IV, en marzo de 1798, que permitía regresar a los jesuitas. Gracias a la relación epistolar que mantenía con Italia, menciona en su Diario el paso de Pío VI por Bolonia y describe los hechos de una forma estremecedora:

«(...) se le dispuso arrebatadamente hospedaje en el Colegio de San Clemente de los españoles. Llegó el día 29 de marzo por la tarde ${ }^{83}$ y algunos ex jesuitas tuvieron el honor de ayudarle a baxar de la carroza o por lo menos de echar la mano para llevarle a la habitación que le estaba destinada. Las cartas que vienen de allí nos lo pintan baldado de medio cuerpo para abajo, sin movimiento y como una gran torre de carne, inmoble o poco menos y como un hombre encantado que mira y no ve ya, y que no acierta a hablar, y del que casi

\footnotetext{
${ }^{80}$ ARCE, Pedro Labrador a Simón Rodríguez Laso, Florencia, 28 de marzo de 1799, Protección y Restablecimiento II, leg. 9, $\mathrm{n}^{\circ} 1$.

${ }^{81}$ Baldassari, P. 1842. Relazione delle avversità e patimeti del glorioso papa Pio VI negli ultimi anni del suo pontificato. tomo IV: 22-28. Módena: Reale tipografia degli erederi Soliani.

${ }^{82}$ Tavanti, G. B. 1804. Fasti del S. P. Pio VI, tomo III: 379. Gio g. Chiari.

${ }^{83}$ Es errónea esta fecha, el Papa llegó el día 30.
} 
se podría dudar si piensa alguna cosa. No obstante uno de los más íntimos de su consulta aseguraba que regía bastante bien de la cabeza». ${ }^{84}$

Por una carta del rector se conoce la hora que llegó al Colegio, las cinco de la tarde, y algún detalle más. Laso afirmaba que «el Colegio hizo de buena voluntad todo el gasto, sin permitir que se recibiese por la familia ni las propinas que querían dar a nombre de Su Santidad». Agradecía Laso la disponibilidad del barón José de Cappelletti, que acompañó en todo momento a los colegiales ${ }^{85}$ A la mañana siguiente la comitiva, por orden del capitán francés Mongen, partió hacia Módena. Antes de la salida, Pío VI escuchó misa en la capilla de San Clemente, en el mismo Colegio, y agradeció con gran afecto al rector y a los dos colegiales su acogida. Los tres, en señal de respeto, besaron devotamente los pies del Papa como también hicieron algunos boloñeses que lograron entrar.

El Liber de Rebus Gestis proporciona poquísima la información sobre la estancia del Papa. Se afirma la satisfacción mayor de los últimos tiempos fue para Laso y los colegiales había el hospedar al Papa y a su comitiva, El Colegio fue «un lugar de consuelo, y aún si vale decirlo así, de asilo a Su Santidad». Solamente aporta el nombre de los prelados que pernoctaron: el cardenal arzobispo de Toledo, Francisco Antonio de Lorenzana, y los auditores de la Rota, monseñores Antonio Gardoqui y Dionisio de Bardaji y Azara ${ }^{86}$ que no siguieron en la comitiva papal y se quedaron algún tiempo en el Colegio. ${ }^{87}$

La acogida causó una profunda y grata impresión en la Corte. El embajador del Rey en Florencia se apresuró a escribir a la Secretaría de Estado y al Rey Carlos IV, dando cuenta de lo sucedido. ${ }^{88}$ Urquijo comunicó tiempo después a Laso que «S. M. que ha estimado mucho esta atención del Real Colegio, me ha mandado decir a V. S. que queda satisfecho por su proceder».$^{89}$ A pocos meses de su salida de Bolonia fallecía el Papa Braschi en Valence-sur-Rhône, Francia. El colegio cardenalicio, al no poder reunirse en Roma, lo hizo en Venecia. Fue elegido Papa con el nombre de Pío VII, el cardenal Chiaramonti, arzo-

${ }^{84}$ ASL, Diario del padre Luengo, tomo XXXIII, pp. 70-71.

${ }^{85}$ AGS, Simón Rodríguez Laso a Mariano Luis de Urquijo, Bolonia, 12 de abril de 1799, secc. Estado, leg. 4748.

${ }^{86}$ Dionisio Bardaji, creado cardenal en el consistorio de 1816, era hermano de Eusebio de Bardaji y Azara, que había sido colegial entre 1790 y 1795. En Pérez Martín, A. 1979. Tomo III: 1756-1759. La filiación familiar y ascendientes de ambos puede verse detalladamente en Cadenas y Vicent, V. 1981. Tomo II: 37 y 38. Madrid: Hidalguía.

${ }^{87}$ ARCE, Liber de Rebus Gestis II, fol. 296 vto.

${ }^{88}$ ARCE, Pedro Labrador a Simón Rodríguez Laso, Florencia, 13 de abril de 1799, Protección y Restablecimiento II, leg. $9, \mathrm{n}^{\circ} 3$.

${ }^{89}$ AGS, Mariano Luis de Urquijo a Simón Rodríguez Laso, 15 de mayo de 1799, secc. Estado, leg. 4748. 
bispo de Imola. Antes de la elección, Simón Rodríguez Laso ofreció al cardenal Lorenzana el Colegio como residencia para el futuro Papa cuando regresara a Roma. El cardenal prometió a comunicárselo al nuevo pontífice, y así lo hizo. ${ }^{90}$ Pío VII lo agradeció a aceptó la invitación, ${ }^{91}$ pero al viajar por mar de Venecia a Pesaro y desde aquí a Roma, no hubo lugar.

El Colegio albergó años más tarde ilustres huéspedes, miembros de la dinastía reinante en España. La Casa de Borbón, desde la extinción de los Farnesio, ocupaba el trono del Gran Ducado de Parma y fue también víctima de los planes imperialistas de Napoleón y de la debilidad del Rey de España. Por el tratado de Luneville, entre Francia y Austria, el Gran Duque de Toscana renunciaba a sus estados, recibiendo a cambio una indemnización en Alemania. Toscana se entregaba al Duque de Parma, Infante de España. Todo ello quedó ratificado por un tratado secreto entre Carlos IV y Bonaparte firmado en La Granja el 1 de octubre de 1800. En él se convenía que, siendo un miembro de la familia real española quien se iba a introducir en la Toscana, sería considerado este estado como propiedad de España, debiendo reinar, en adelante, un infante de la familia de los reyes de España. ${ }^{92}$ Una vez firmado el acuerdo, Carlos IV envió a sus hijos a su nuevo reino, recomendándoles que pasasen por París para agradecer a Napoleón Bonaparte la firma del tratado.

Simón Laso, enterado de que los reyes de Etruria se encontraban en Parma preparando su viaje para pasar a Florencia, escribió al ministro del Rey para que les ofreciese alojarse en el Colegio. Antes de entrar en la Toscana, los reyes de Etruria, Luis I y María Luisa, se detuvieron en Bolonia y descansaron en el Colegio el 10 de agosto de $1801 . .^{93}$

En 1805 la princesa Carlota, hija del difunto Duque de Parma, religiosa dominica en el convento de Colorno con el nombre de sor Jacinta Dominga, debía transferirse desde Parma a uno de los convento de su orden en Roma. La princesa, personalmente, dejó encargado a sus acompañantes, Gerónimo de la Grua, antiguo ministro del Rey en Parma, y a su esposa, que quería alojarse en el Real Colegio a su paso por Bolonia. De la Grua realizó las gestiones pertinentes con el rector avisándole de la composición del cortejo, formado por un total de diez personas, entre ellas, tres religiosas. Solicitaba que se dispusieran

\footnotetext{
${ }^{90}$ ARCE, Francisco de Lorenzana a Simón Rodríguez Laso, Venecia, 24 de enero de 1800, Epistolarum, «Cardenales», leg. 100, $\mathrm{n}^{\circ} 7$.

${ }^{91}$ ARCE, Francisco de Lorenzana a Simón Rodríguez Laso, Venecia, 29 de marzo de 1800, Epistolarum, «Cardenales», leg. $100, \mathrm{n}^{\circ} 8$.

${ }^{92}$ Cardell, C.1954. La Casa de Borbón en España: 100 y 101. Madrid: La Rafa. Para acercarse a la política de España en Italia durante los primeros años del siglo XIX, es de especial interés el libro de Jack Berte-Languereau La política italiana de España bajo el reinado de Carlos IV, publicado en 1958.

${ }^{93}$ ARCE, Liber de Rebus Gestis II, fol. 358 vto.
} 
dos cuartos independientes pero sin lujo ni ostentación alguna, pues así lo pedía la misma princesa. ${ }^{94}$

Durmieron en el Colegio la noche del 8 de junio. Laso recibió el reconocimiento del gobierno de España por el trato y las deferencias con la comitiva de la princesa Carlota, comunicadas por el secretario de Estado, Pedro de Cevallos, al jefe de la comitiva, Gerónimo de la Grua. ${ }^{95}$

La relación del Colegio con el gobierno de Madrid, debía ser en aquellos momentos óptima. Así puede entenderse que el rector solicitase a Pedro de Cevallos, que el Rey dispensase de pruebas de limpieza de sangre a Francisco Rodríguez Laso, su sobrino, presentado para una plaza colegial por el marqués de Ariza,${ }^{96}$ favor concedido un mes después. ${ }^{97}$ Igualmente en 1806, aprovechando las buenas relaciones con la Secretaría de Estado, Laso escribió a Cevallos para que presentase al monarca su deseo de formar parte del Consejo del Rey, ${ }^{98}$ del que ya eran miembros sus compañeros de colegiatura Campomanes, de Simón, Villela y el obispo de Palencia, pero su petición no fue atendida. ${ }^{99}$

En 1807 hubo otra visita importante. El tratado de Fontainebleau de 1807 supuso la renuncia de la Reina regente de Etruria y su exilio. El 10 de diciembre de 1807, la Reina abandonaba el Palacio Pitti de Florencia con una larga comitiva. El día 14 se detuvo en Bolonia y pasó la noche en el Colegio. La Reina María Luisa de Borbón y Borbón-Parma fue el último huésped ilustre

\footnotetext{
${ }^{94}$ ARCE, Gerónimo de la Grua a Simón Rodríguez Laso, Parma, 4 de junio de 1804, Epistolarum, «Especiales» leg. 19, n ${ }^{\circ} 74 a$.

${ }^{95}$ ARCE, Pedro de Cevallos a Gerónimo de la Grua, Madrid, 15 de julio de 1805, Epistolarum, «Especiales», leg, 19, no 74c.

96 AMAE, Simón Rodríguez Laso a Pedro de Cevallos, Bolonia, 20 de septiembre de 1805, leg. P- 822, exp. 11601 .

${ }^{97}$ AMAE, nota de la primera Secretaría de Estado a Simón Rodríguez Laso, San Lorenzo del Escorial, Madrid, 15 de octubre de 1805, leg. P-822, exp. 11601.

${ }^{98}$ AMAE, Simón Rodríguez Laso a Pedro de Cevallos, Bolonia, 31 de agosto de 1806, leg. P-822, exp. 11601.

${ }^{99}$ No se conserva la respuesta de Pedro de Cevallos en el expediente personal de Laso custodiado en el archivo del Ministerio de Exteriores. Viendo el libro del Consejo correspondiente al año 1806 se llega a la conclusión de que no le fue concedida la merced que solicitaba, ya que su nombre no figura entre los consejeros, como tampoco aparece en los del año siguiente (AHN sección Consejos, signaturas L. 1396, p. 3 y ss. y L. 1397 p. 3 y ss.). No aparece como consejero del Rey en la solicitud que realiza su sobrino Francisco Rodríguez Laso en su nombre para ocupar el cargo de Auditor de la Rota en 1815, en la que da cuenta de todos sus méritos y distinciones (AMAE, Memorial presentado al Rey Fernando VII a favor de su tío, el Dr. D. Simón Rodríguez, Laso para la concesión de los honores del tribunal de la nunciatura, Madrid, 4 de marzo de 1815. leg. P- 822, exp. 11601) ni en los méritos de los académicos de la Real Academia de la Historia publicados en 1817 (Memorias de la Real Academia de la Historia, tomo V: 59. Madrid). Igualmente no aparece Laso como Consejero en el estudio de Ricardo Gómez-Rivero, publicado en 1996, «Consejeros de Castilla en el reinado de Carlos IV», en Homenaje al profesor Alfonso García Gallo: 199. Madrid: editorial Complutense.
} 
del Colegio del que hay constancia durante el rectorado de Laso. El colegial «historiador» relata así los hechos en un texto que por su interés se reproduce:

«Dependiente del destino de los pequeños soberanos de Italia de la política del emperador de los franceses, Napoleón Bonaparte, siendo inminente el arrivo de los reyes de Etruria al paso por esta ciudad para encaminarse a España por disposición del mismo Emperador, y debiéndose alojar en este Real Colegio con las principales personas de su comitiva, según los deseos de S. M. que le fueron comunicados [al rector Laso] por el señor don Pedro Gómez Labarador, ministro de S. M. Católica en Florencia, se dieron las disposiciones convenientes a este fin y órdenes al ecónomo para que procediese con moderación en todo, sin faltar al decoro correspondiente a tan dignos huéspedes, y se verificó su hospedaje en el día catorce de diciembre de este año. Los principales personajes fueron: la reyna, los dos sagliacis camaristas, la duquesa Strozzi y su camarera con dos guradarrobas, la infanta, azafata y camaristas, la duquesa Granero, su camarera, conde y condesa Guiciardini y camarera, médico cirujano, boticario, confesor, oficial de la guardia, credencieros y cocineros y más de 24 sirvientes; en todo como unas cincuenta personas. Esta vez quisieron S. M. satisfacer el coste de los gastos, y además regalaron para la familia cien franciscones. También decía que S. M. la reyna habia destinado un magnifico coche con hermosos caballos para el Colegio y que se apoderó de él un general francés». ${ }^{100}$

\section{LA ClAUSURA NAPOLEÓNICA DEL COLEGIO Y LOS ÚlTiMOS AÑOS DEL LASO EN BOLONIA}

En 1810, la Corte comisionó al antiguo embajador de España en Milán, Nicolás Blasco de Orozco, para una inspección del Real Colegio de Bolonia. Las indagaciones fueron puramente económicas. Las ganancias anuales por el cultivo de sus tierras ascendían a 37.113 libras de Bolonia y sus gastos, a 36.720. Orozco remitió copia del testamento del cardenal y recomendó la conservación de la Casa, al ser «la más antigua de Europa e insigne por los distinguidos servidores que ha proporcionado al Estado». Indicaba solo que era necesario restaurar parte de las construcciones en las posesiones rústicas, pues se encontraban en pésimo estado, y pagar una deuda de 4.153 libras a una obra de caridad que realizaba al hospicio de pobres sacerdotes de Bolonia. ${ }^{101}$ Pese a las noticias, Napoleón decidió apoderarse de las propiedades de España en Italia. El pretexto era proveer las pensiones de los jesuitas españoles expulsos que residían en Italia. El 28 de marzo de 1812, Napoleón, como Rey de Italia, firmó este decreto:

${ }^{100}$ ARCE, Liber de Rebus Gestis II, fol. 306 vto.

${ }^{101}$ AMAE, Informe realizado por D. Nicolás Blasco de Orozco sobre el estado del Colegio de Bolonia, sin lugar ni fecha, leg. Tratados, SS 0039, exp. 17.

Hispania Sacra, LXV

131, enero-junio 2013, 275-308, ISSN: 0018-215-X, doi: 10.3989/hs.2013.009 
«Napoleone Re, Volendo provvedere alla sussistenza degli exGesuiti spagnoli dimoranti sul Regno d'Italia abbiamo decretato e decretiamo quanto sigue:

Art. $1^{\circ}$ Le pensione vitalizie dovute dalla spagna agli ez-Gesusiti spagnoli dimoranti sul Regno d'Italia saranni pagate dal Monte Napolene a corre dal primo Gennaio del corrente anno.

Art. $2^{\circ}$ In compenso d'questo aggravio saranno avocati al Monte Napoleone i beni del caso detto Collegio di Spagna in Bologna e qualunque altrzione Spagnola esistente nel Regno d'Italia.

Art. $3^{\circ}$ Il Ministro delle Finanze del Regno d'Italia e incaricato dell'execuzione del presente decreto». ${ }^{102}$

El 11 de abril Laso y los colegiales firmaron su oposición, asegurando que era público y notorio que los bienes del Colegio no pertenecían a la nación española, sino que eran de una fundación privada, constituidos por su fundador como legado. Alegaban también que, si el gobierno italiano había resuelto que las rentas sirviesen para pagar las pensiones de los ex jesuitas españoles, renunciarían al disfrute de ellas, pero las fincas debían quedar intactas hasta que la Corte de España resolviese de forma conveniente, sobre todo al tratarse del pago de unas pensiones vitalicias, para lo que era indispensable un fondo permanente.

Los mismos sentimientos hicieron presentes al Prefecto del Monte de Napoleón en Milán, Luis Castigliani, al que se conminó también para que, si se permitiese la existencia del Colegio, se destinara el producto de las plazas vacantes o que fueran quedando libres a socorrer a los jesuitas. Pero el ministro de Hacienda desestimó la reclamación del rector, pues carecía de personalidad para realizar protesta alguna y le ordenó que antes de 1 de julio desalojasen el Colegio los colegiales y sirvientes. ${ }^{103}$ Días después del decreto, un delegado del director del Demanio de Bolonia en el que había delegado el Prefecto del Monte de Napoleón, tomó posesión de los bienes procediendo al inventario de todos los muebles e inmuebles.

Con la orden de evacuación se remitían también una serie de indemnizaciones: 250 libras italianas para el rector, 200 para los colegiales y 100 para los dependientes que hubiera en la Casa en aquel momento. Las indemnizaciones se cobrarían cada tres meses. ${ }^{104} \mathrm{El}$ edificio sufrió numerosos daños, desapareciendo un cuadro de Rafael que se conservaba en la capilla, y la mayoría de los

${ }^{102}$ AMAE, Relazione intorno al Collegio di Spagna desunta dagli atti e documenti esistente in Archvio, sin lugar ni fecha, leg. H 4319.

${ }^{103}$ AMAE, Extracto, traducción y notas de los documentos relativos a la suspensión del Rl. Colegio mayor de Sn. Clemente de los Españoles fundado en Bolonia por el Emmo. Sor. Cardenal Dn. Gil de Albornoz desde el año 1365, fol. 1 vto., leg. P- 822, exp. 11601.

${ }^{104}$ Ibídem, fols. 1 vto. y 2. 
retratos de los colegiales. La magnífica biblioteca y el archivo pudieron salvarse gracias a la ayuda del cardenal Mezzofanti, antiguo capellán, que trasladó los libros y manuscritos a la biblioteca de la Universidad de Bolonia. ${ }^{105}$

Todo ello fue comunicado al duque de Santafé, primer secretario de Estado, en una carta firmada por el rector y los colegiales Vicente Adam, Joaquín Cáceres, Francisco Rodríguez Laso y Joaquín Mezquita. En ella suplicaban además que protegiese al establecimiento e interpusiera sus buenos oficios en favor del Colegio.${ }^{106}$ Pero inútiles eran sus súplicas a un gobierno dirigido por el propio hermano de Napoleón. Santafé contestó tiempo después abandonando el Colegio a su suerte. José I conocía las pensiones asignadas a Laso y a los colegiales y «aunque se propone practicar los oficios convenientes con el objeto de la subsistencia del Colegio, como el éxito de ellos [de los colegiales] es incierto, dexa S. M. al arbitrio de V. I. y de los colegiales el tomar, según las circunstancias que sobrevengan, el partido que cada uno conviniese». Acababa su demoledora carta a Laso pidiéndole que cuidara especialmente de todos los papeles y antigüedades que pudiera haber en el archivo y biblioteca del Colegio. ${ }^{107}$

Sin apoyo de la Corte de España ni del gobierno de Bolonia, Laso y los colegiales abandonaron el Colegio. Muy dura debió ser la salida, tal y como recoge el propio rector en una carta de 1814. «Se posesionó también del local del Colegio donde se hallaban recogidos los individuos del mismo, sacándolos duramente, dejándolos sin asilo, en tierra extraña, en un tiempo en que con motivo de las vicisitudes de la guerra con España, no se les permitía volver al seno de sus propias familias». ${ }^{108}$

Hay una incógnita sobre la vida de Simón Laso. No se ha logrado establecer con certeza dónde residió mientras estuvo clausurado el Colegio. Ni una sola carta de esos años se ha encontrado en los archivos consultados. Todo hace pensar que se trasladó junto a su sobrino a Génova. En abril de 1815, Francisco Rodríguez Laso se encontraba provisionalmente en Madrid y pidió pasar a Génova «para estar más inmediato a mi familia» ${ }^{109} \mathrm{y}$, por tanto, puede pen-

${ }^{105}$ Gil Fernández, I. 1964. De codicibus albornotianis ad graecas latinasque litteras pertinentibvs commentarivs: 35 . Bolonia: Zanichelli.

${ }^{106}$ AMAE, el rector y los colegiales del Real Colegio de España al duque de Santafé, Bolonia, 15 de abril de 1812, leg. Tratados, SS 0039, exp. 17.

${ }^{107}$ AMAE, el duque de Santafé a Simón Rodríguez Laso, Madrid, 16 de junio de 1812, leg. Tratados, SS 0039, exp. 17

${ }^{108}$ AMAE, Extracto, traducción y notas de los documentos relativos a la suspensión del Rl. Colegio mayor de Sn. Clemente de los Españoles fundado en Bolonia por el Emmo. Sor. Cardenal Dn. Gil de Albornoz desde el año 1365, fols. 2 vto. y 3, leg. P- 822, exp. 11601.

${ }^{109}$ AMAE, carta de Francisco Rodríguez Laso, no se indica el receptor, Madrid, 18 de abril de 1815 , leg. P-217, exp. 12146.

Hispania Sacra, LXV

131, enero-junio 2013, 275-308, ISSN: 0018-215-X, doi: 10.3989/hs.2013.009 
sarse que al hablar de su familia se refería a su tío, el rector. El antiguo colegial Ignacio Martínez de Villela, en una carta, en la que recomienda a Laso para Auditor de la Rota, habla de su emigración reciente a Génova» con motivo de la ola revolucionaria que se produjo en Italia. Génova es, pues, la opción más posible que puede barajarse como lugar de residencia de Simón Laso durante la clausura del Colegio. ${ }^{110}$

La caída de Napoleón cambió la situación en Bolonia, que quedó bajo la protección de la Corte de Austria. Muy poco después, el rector y los dos colegiales que habían permanecido en Italia, se apresuraron a escribir al Barón De Khardt, gobernador militar de Bolonia, pidiendo la restitución de los bienes del Colegio, incorporados al Monte de Napoleón en virtud del decreto de 28 de marzo de 1812.

Laso comenzaba explicando que, después de 447 años de su fundación, el Colegio fue repentinamente clausurado por el decreto, que vulneraba todos los principios del derecho, públicos y privados. Los bienes eran de carácter estrictamente privados, pues procedían de un legado a del cardenal Albornoz, habían sido tratados como bienes, propiedad de la nación española. Se había así usurpado una propiedad privada. Laso y los colegiales pedían al gobernador que patrocinase su justa reclamación «fundada en los derechos más sagrados de la propiedad particular, ultrajada por la fuerza y prepotencia, contra todo principio de razón», restituyendo los bienes que todavía se hallaban en posesión de Demanio de Bolonia y los comprados por terceros, que debían ser indemnizados con alguna cantidad, pero debían ser devueltos. ${ }^{11}$

Laso inició las gestiones encaminadas al restablecimiento de la fundación con el delegado apostólico en la ciudad, monseñor Giustiniani, y con el general austriaco Steffanini, encargado militar. Se presentó ante el Papa y el secretario de Estado con anuencia de representante español ante el Papa, Antonio Vargas Laguna.

Por una de sus cartas se sabe que la entrevista con el Pontífice fue en Bolonia, aprovechando el paso Pío VII por la ciudad. ${ }^{112}$ En ella, el Papa «prometió hacer cuanto dependiese de su arbitrio a favor del Colegio» y oyó las reclamaciones

${ }^{110}$ AMAE, Ignacio Martínez de Villela a Pedro de Cevallos, Madrid, 25 de mayo de 1815, leg. P-822, exp. 11601.

${ }^{111}$ AMAE, Extracto, traducción y notas de los documentos relativos a la suspensión del Rl. Colegio mayor de Sn. Clemente de los Españoles fundado en Bolonia por el Emmo. Sor. Cardenal Dn. Gil de Albornoz desde el año 1365, fols. 2-4, leg. P-822, exp. 11601.

${ }^{112}$ Sin duda se trata del viaje de regreso del Pío VII de su cautiverio francés a Roma. El Papa llegó a la ciudad el 24 de mayo de 1814. Sobre su estancia en Bolonia puede verse la obra de Fanti M. y Roversi, G. 1999. Papi a Bologna e Papi Bolognesi, Giubilei e Pellegrinaggi: 101-103. Bolonia: HitStudio. 
del rector. El Papa Chiaramonti le insinuó inmediatamente que los bienes no vendidos podían restituirse, mientras que los enajenados presentaban dificultades conforme a lo acordado a los artículos 97 y 103 del Congreso de Viena. ${ }^{113} \mathrm{El}$ secretario de Estado, Ercole Consalvi, ${ }^{114}$ con quien también se entrevistó, le dijo que habiendo ofrecido el Papa no inquietar a los compradores, el gobierno pontificio no podía mezclarse en ese asunto, pero le conminó a que usara el derecho que le correspondía reclamando los bienes ante los tribunales de justicia. ${ }^{115}$

Un año más tarde, en septiembre de 1815, ante la pasividad de las autoridades pontificias, el rector se presentó de nuevo ante el Papa y el secretario de Estado en Roma. En la audiencia con el Pontífice y con el cardenal, según Vargas Laguna, el rector «dio (...) los pasos que reputó necesarios para obtener la restitución de los bienes pertenecientes a su Colegio» pero ambos se limitaron a contestar lo ya consabido y estipulado en el Congreso de Viena. Vargas en este mismo informe da cuenta de un hecho clave para entender la situación de las reclamaciones. El cardenal Consalvi era íntimo amigo del conde Aldini, ${ }^{116}$ comprador de los bienes del Colegio «y a estas relaciones atribuyo el empeño de sostener una adquisición tan injusta». ${ }^{117}$

Ante la situación, el diplomático español pidió al cardenal-secretario de Estado su intervención benévola en el asunto. Fue recibido por el Papa para tratar exclusivamente de la restitución de la fundación. El Papa y el secretario de Estado reconocieron que las notas que les había presentado eran incontestables, que toda la razón estaba de su parte «pero que las deliberaciones del Congreso les impedían executar lo mismo que deseaban». Por estas reclamaciones, el 15

${ }^{113}$ El artículo 97 se refería a la necesidad de conservar por algún tiempo el llamado Monte de Napoleón. El 103, en cambio, declaraba que tenían validez las adquisiciones hechas por los particulares durante el dominio napoleónico «a consecuencia de un título reconocido legal por las leyes vigentes en la actualidad». En Cantillo y Jovellanos, A del. 1843. Convenios y Declaraciones de paz y de comercio que han hecho con las potencias extrajeras los monarcas españoles de la Casa de Borbón. 770-771. Madrid: Imprenta de Alegría y Charlain.

${ }^{114}$ Pese a que son detalladas y es ingente la información que proporcionan, no aparece en las Memorias de Consalvi mención alguna a las negociaciones para el restablecimiento del Colegio de San Clemente. Las memorias del Cardenal fueron publicadas en París en 1864 bajo el título Mémoires du cardinal Consalvi.

${ }^{115}$ AMAE, Simón Rodríguez Laso a Antonio Vargas Laguna, Roma, 16 de septiembre de 1815, leg. Tratados, SS 0039, exp. 17.

${ }^{116}$ La figura de Antonio Aldini estaba estrechamente ligada al Colegio ya que durante años había sido abogado del mismo. Su biografía en Zanolini A. 1864-67. Antonio Aldini e $i$ suoi tempi. Florencia: F. Le Monnier. También Angelo Varni, en la ya citada Bologna Napoleonica, habla detenidamente de Aldini y su actuación durante la dominación napoleónica

117 AMAE, Antonio Vargas Laguna a Pedro de Cevallos, Roma, 30 de septiembre de 1815, leg. Tratados, SS 0039, exp. 17. 
de octubre de 1815, fueron restituidos el palacio del Colegio, los bienes no vendidos, la biblioteca, el archivo y los muebles existentes. ${ }^{118}$

La solución para que la fundación tuviera nueva vida y abriera sus puertas fue resultado de una negociación entre Vargas y el secretario de Estado que duró casi tres años. De ella permaneció al margen, aunque estuvo puntualmente informado, Simón Rodríguez Laso. El Papa delegó facultades en el cardenal Consalvi y se estipuló un tratado de indemnización por los bienes que le habían sido arrebatados. El gobierno pontificio asignó anualmente a la fundación una renta anual de 3.500 escudos romanos.

La propuesta se plasmó el 29 de diciembre de 1818 en un convenio entre España y la Santa Sede por el cual «Su Santidad además de los bienes que ya se han restituido al Colegio de San Clemente y de los cuales se halla ya en posesión, señalará al mismo tiempo tantos fondos como sean necesarios para constituir en la actualidad una renta anual de tres mil quinientos escudos, quedando dichos fondos en propiedad del citado Colegio». A cambio, la Corte de Madrid cedía al gobierno pontificio el crédito de las pensiones debidas a los ex jesuitas españoles por la adscripción al Monte de Napoleón de los bienes del Colegio de Bolonia, por un montante anual de 146.000 pesetas. ${ }^{119}$ Según Pérez Martín, la indemnización significaba aproximadamente la mitad de las pérdidas sufridas. ${ }^{120}$

Terminaba así una de las etapas más críticas de la historia del Colegio, logrando ser una de las pocas instituciones que sobrevivió al vendaval revolucionario. En 1820, un año antes de su muerte, Laso admitía a los que sería los dos primeros moradores de la Casa tras el restablecimiento de la institución y a su vez sus dos últimos colegiales, José Orive y Argaiz y Antonio Neira y Marín. ${ }^{121}$

En 1815, mientras se resolvían los problemas relativos a los bienes, Simón Laso pidió ser nombrado auditor del tribunal de la Rota. Tras los veintisiete años de su rectorado, solicitaba al Rey esta merced «como una prueba de su Real consideración». ${ }^{122} \mathrm{Su}$ petición fue atendida. ${ }^{123}$

${ }^{118}$ AMAE, Simón Rodríguez Laso a Pedro de Cevallos, Bolonia, 15 de octubre de 1815, leg. Tratados, SS 0039, exp. 17.

${ }^{119}$ Martínez Cardós, J. 1979. «La extinción del Colegio de España en Bolonia en 1812 y su restablecimiento en 1818», en Verdera y Tuells, E. (ed.): Tomo IV: 817.

${ }^{120}$ Pérez Martín, A. 1979. Tomo I: 26.

${ }^{121}$ Ibídem, tomo IV: 1784-1786.

${ }^{122}$ AMAE, Francisco Rodríguez Laso en representación de su tío Simón al Rey Fernando VII, Madrid, 4 de marzo de 1815, leg. P- 822, exp. 11601.

${ }^{123}$ AMAE, Simón Rodríguez Laso a Pedro de Cevallos, Bolonia, 24 de julio de 1815, leg. P-822, exp. 11601. 
Uno de los últimos testimonios sobre Laso se debe a la pluma de Moratín. En su Epistolario cuenta que, en su segundo viaje a Italia, al visitar el Colegio de San Clemente, encontró al rector «siempre el mismo; Arcinaga (su criado) hecho una momia egipcia, uno y otro, tan mezquinos como siempre». ${ }^{124} \mathrm{Un}$ año después, el 26 de diciembre de 1821 a las 12 y media del mediodía, moría Simón Rodríguez Laso en su Colegio. ${ }^{125}$ Su sobrino Francisco fue su heredero universal. ${ }^{126}$

\section{«VIRO ERUDITIONE ET DOCTRINA LITTERATIS HOMINIBUS QUOS PERAMANTER FOVIT PR(o)BATISSIMO»}

Con estas palabras finaliza el epitafio del monumento mortuorio de Simón Laso en el cementerio de la Certosa de Bolonia. Fue respetado por su erudición y doctrina y querido por los hombres de letras, a los que favoreció.

Laso fue un hombre estimado en España y en Italia, donde dedicó su vida a la formación de los colegiales de San Clemente y logró que, pese a las dificultades de todo orden, la fundación aegidiana sobreviviera. La vida de Simón Rodríguez Laso, esbozada en este artículo está claramente ligada a la existencia del Colegio de San Clemente de los españoles de Bolonia, primero como colegial y durante años como rector. Le tocó el paso del Antiguo Régimen al nuevo Estado Liberal, en una institución que arrastraba ya una gran crisis desde hacía varios siglos. Laso vivió en Bolonia una época de profundos cambios en el Colegio, en el contexto de alteraciones generales en las universidades y de enfrentamiento general provocado la laicización de la cultura y la oposición de la Iglesia a las nuevas ideas. En medio de esas innovaciones del momento, su vida estuvo totalmente dedicada a la causa albornociana en Bolonia y a mantener vivo su legado.

La figura de Simón Laso es hoy desconocida como era hasta hace poco la de su hermano Nicolás, Inquisidor en Barcelona y Valencia. El alejamiento de la Corte de Madrid y su dedicación exclusiva a la fundación hacen que este clérigo ilustrado, académico de las academias de la Historia y de San Fernando, promotor de la Sociedad Económica de Ciudad Rodrigo, haya estado ausente de las biografías de los personajes de las Luces españolas. El no haber escrito ninguna obra durante su estancia en Italia, lo aleja más del interés del investigador. Pero ello no desmerece la biografía de un sacerdote que tuvo que adaptarse a las

${ }^{124}$ Fernández de Moratín, N. y L. 2008. Tomo I: 1389.

${ }^{125}$ AMAE, José Orive y Antonio Neira a Eusebio de Bardají y Azara, Bolonia, 30 de diciembre de 1821, leg. P- 822, exp. 11601.

${ }^{126}$ Archivo de Estado de Bolonia, notarile, L. Capelli 1822-4 fol. 93. 
circunstancias posteriores a la Revolución Francesa y convertirse en el principal defensor de la institución que dirigía.

En los muros del Real Colegio de España en Bolonia luce hoy su retrato, entre los del fundador y los hombres más insignes de la institución. Es un homenaje de agradecimiento a este quasi desconocido clérigo ilustrado, que, como rector, lo salvó de su desaparición a finales del siglo xvIII y principios del siglo XIX.

\section{BiBLIOGRAFÍA}

Aguilar Piñal, F. 1993. Bibliografía de autores españoles del siglo XVIII, tomo VII. Madrid: Instituto Miguel de Cervantes del CSIC.

Amat, F. 1807. Tratado de la Iglesia de Jesucristo o Historia Eclesiástica, tomo XII. Madrid: imprenta de Benito García y Compañía

Astorgano Abajo,A. 1998. «La personalidad del ilustrado Don Nicolás Rodríguez Laso (1747-1820), inquisidor de Barcelona y Valencia». Revista de la Inquisición 8: 121-187.

Baldassari, P. 1842. Relazione delle avversità e patimeti del glorioso papa Pio VI negli ultimi anni del suo pontificato, tomo IV. Módena: Reale tipografia degli erederi Soliani.

Basanta de la Riva, A. 1955. Sala de los Hijosdalgo. Catálogo de todos sus pleitos, expedientes y probanzas. Madrid: Hidalguía.

Batllori i Munné, M. 1972. «El Colegio de España a finales del siglo XviII», en Verdera y Tuells, E. (ed.), El cardenal Albornoz y el colegio de España, tomo II. Zaragoza: Cometa.

Beltrán de Heredia, V. 1958 «Los primeros Estatutos del Colegio Español de San Clemente en Bolonia,» Hispania Sacra 11: 187-224 y 409-426.

Berte-Languereau, J. 1958. La política italiana de España bajo el reinado de Carlos $I V$. Madrid: Revista de Occidente.

Bertrán Roigé, P. 1979. «Ceremonias fúnebres por los monarcas españoles», en Verdera y Tuells, E. (ed.), El cardenal Albornoz y el Colegio de España, tomo V. Zaragoza: Cometa.

Borrajo y Herrera, P. y Giner de los Ríos, H. 1888. El Colegio de Bolonia, centón de noticias relativas a la fundación hispánica de San Clemente. Madrid: imprenta de M. Minuesa de los Ríos.

Cadenas y Vicent, V. 1981. Extracto de los expedientes de la Orden de Carlos $3^{\circ}$, 1771-1847, tomos II y XI. Madrid: Hidalguía.

Cantillo y Jovellanos, A del. 1843. Convenios y Declaraciones de paz y de comercio que han hecho con las potencias extrajeras los monarcas españoles de la Casa de Borbón. Madrid: Imprenta de Alegría y Charlain. 
Cardell, C.1954. La Casa de Borbón en España. Madrid: La Rafa.

Castellanos de Losada, B. S. 1850. Biografía del célebre diplomático y distinguido literato español D. José Nicolás de Azara y Perera. Madrid: D. G. González.

Consalvi, E. 1864. Mémoires du cardinal Consalvi. París: Henri Plon Imprimeur-Éditeur.

Covarrubias de Orozco, S. 1995. Tesoro de la lengua castellana o española. Madrid: Castalia.

Corona y Baratech, C. E. 1948. José Nicolás de Azara. Zaragoza: Institución Fernando el Católico.

Cuart Moner, B. 1979. «Diego de Neila, colegial de Bolonia, canónigo de Salamanca y amigo de Juan Ginés de Sepúlveda», en Verdera y Tuells, E. (ed.), El cardenal Albornoz. y el Colegio de España, tomo VI. Zaragoza: Comenta.

Demerson, P. y J. «La Sociedad Económica de Amigos del País de Ciudad Rodrigo». Cuadernos de historia moderna y contemporánea 3: 35-60.

Fanti M. y Roversi, G. 1999. Papi a Bologna e Papi Bolognesi, Giubilei e Pellegrinaggi. Bolonia: HitStudio.

Fernández Arrillaga, I.:

2002. Memorias de un exilio. Diario de la expulsión de los jesuitas de los dominios del Rey de España (1767-1768). Manuel Luengo, S. I. Alicante: San Vicente de RaspeigPublicaciones de la Universidad de Alicante.

2003. El legado del P. Manuel Luengo. S. I. Alicante: Instituto de Cultura Juan Gil-Albert.

2004. El retorno de un jesuita desterrado. Viaje del padre Luengo desde Bolonia a Nava del Rey (1798). Alicante: San Vicente de Raspeig-Publicaciones de la Universidad de Alicante.

Fernández de Moratín, N. y L. 2008. Obras Completas. Navarra: Cátedra.

Gil, L.1979. «Jacinto Díaz Miranda, colegial de San Clemente y traductor de Marco Aurelio», en Verdera y Tuells, E. (ed.), El cardenal Albornoz y el Colegio de España, tomo V. Zaragoza: Cometa.

Gil Fernández, I. 1964. De codicibus albornotianis ad graecas latinasque litteras pertinentibvs commentarivs. Bolonia: Zanichelli.

Gómez-Rivero, R. 1996. «Consejeros de Castilla en el reinado de Carlos IV», en Homenaje al profesor Alfonso García Gallo: Madrid: editorial Complutense.

Lario Ramírez, D. de. 1979. «El Colegio de San Clemente de Bolonia durante la impermeabilización hasburguesa (1568-1659)», en Verdera y Tuells, E. (ed.), El cardenal Albornoz y el Colegio de España, tomo IV. Zaragoza: Cometa. 
Martínez Cardós, J. 1979. «La extinción del Colegio de España en Bolonia en 1812 y su restablecimiento en 1818», en Verdera y Tuells, E. (ed.), El cardenal Albornoz y el colegio de España, tomo IV. Zaragoza: Cometa.

Nieto Sánchez, C.:

2011. «Un capítulo inédito de la reforma de los colegios mayores universitarios: la visita de Pérez Bayer a los colegios españoles en Bolonia». Revista de investigaciones históricas 31: 93-114.

«La rappresentanza del Re di Spagna nella città di Bologna. Il barone Giussepe Cappelletti». Nobiltà 101: 243-256.

2012. San Clemente de Bolonia (1788-1899): el fin del Antiguo Régimen en el último colegio mayor español. Madrid: publicaciones de la Universidad Carlos III.

Marti, Berthe M. 1966. The Spanish College at Bologna in the Fourteenth Century, edition and Translation of its statutes, with introduction and notes. Filadelfia: University of Pennsylvania Press.

Olaechea Albistur, R. 1980. El Cardenal Lorenzana en Italia. León: Institución Fray Bernardino de Sahagún de la Excma. Diputación Provincial.

O’Neill, C. E y Domínguez, J. M. 2001. Diccionario histórico de la Compañía de Jesús, tomo III. Madrid: Universidad Pontificia de Comillas.

Pastor, L. Von. 1953. Storia dei Papi dalla fine del Medioevo, tomo XVI. Roma: Desclée \& C. editori pontifici.

Pérez Martín, A. 1979. Proles aegidiana, tomo III. Zaragoza: Cometa.

Rodríguez Laso, N. 2006. Diario en el viage de Francia e Italia (1788). Zaragoza: Institución Fernando el Católico.

Sin autor:

1817. Memorias de la Real Academia de la Historia, tomo V. Madrid

1981. Guida generale degli Archivi di Stato italiani, tomo I. Roma.

Tavanti, G. B. 1804. Fasti del S. P. Pio VI, tomo III. Gio g. Chiari.

Tejerina, B. 1979. «Leandro Fernández de Moratín y el Colegio de España», en Verdera y Tuells, E. (ed.), El cardenal Albornoz y el colegio de España, tomo VI. Zaragoza: Cometa.

Varni, A. 1973. Bologna Napoleonica. Bolonia: Massimiliano Boni.

Zanolini A. 1864-67. Antonio Aldini e i suoi tempi. Florencia: F. Le Monnier. 